\title{
А.М. Бондаренко
}

\section{ВАКЦИНАЦІЯ - ОЦІНКА ДОЦІЛЬНОСТІ ТА РИЗИКІВ}

Криворізький національний університет, Центр діагностики та лікування інфекційних хвороб, м. Кривий Ріг

Дослідження присвячене сучасним проблемам імунопрофрілактики керованих інфрекцій. Висвітлені актуальні питання індивідуальної вакцинації, оцінки ії доцільності, а також профрілактика тяжких поствакцинних ускладнень.

Наведені дані (з урахуванням рекомендацій ВООЗ) про індивідуальні захисні рівні специсрічних антитіл у сироватці крові людини відносно конкретних керованих інфеекцій. Висвітлені проблеми уніфрікації, стандартизації та міжнародних стандартів показників захисного рівня антитіл, визначених за різними методами дослідження. Описані показники колективного імунітету та їх співвідношення з рівнями індивідуального захисного рівня антитіл.

Наведені дані, які базуються на визначенні рівня специорічних захисних антитіл, та обгрунтовують регламент оцінки доцільності, необхідності та небезпеки проведення індивідуальної імунопрофрілактики для конкретної керованої інфрекції у конкретного пацієнта.

Обірунтована можливість прогнозування тяжких алергічних поствакцинних реакцій з використанням «старих» та невиправдано забутих способів і методів оцінки. Запропоновано відновлення та методологію застосування реакції імунолейкоцитолізу з вакцинними антигенами сучасних вакцин.

Об'єктивно обірунтована необхідність практичної реалізації саме індивідуальних програм вакцинації та ревакцинації. Запропонований наступний алгоритм індивідуальної імунопрофрілактики інфекцій: спочатку - оцінка необхідності у конкретній вакцинації, яка визначається за рівнем специорічних захисних антитіл (з урахуванням рекомендацій ВООЗ); на другому етапі - оцінка доцільності вакцинації; на третьому етапі, за необхідності та/або доцільності їі проведення всебічна оцінка можливості специсрічної імунопрофрілактики з урахуванням клінічних протипоказань, а також індивідуальних ризиків, побічних ефектів та небезпеки розвитку алергічних реакцій негайного типу при використанні конкретної вакцини у конкретного пацієнта.

Запропонований алгоритм та використання методів прогнозування імунопатологічних реакцій на вакцини не дає 100 \% гарантії безпеки, але безумовно зводить небезпеку імунопрофрілактики до досяжного на сьогодні можливого мінімуму i, найголовніше, - дає можливість пацієнту усвідомлено разом із клініцистом ухвалювати рішення про застосування конкретної вакцини, а в разі розвитку можливих, але не прогнозованих, ускладнень вакцинації усуне проблеми юридичної відповідальності клініциста.

Рекомендоване обов'язкове створення відповідних нормативних документів, у яких замість бездумного «протоколу» буде детально відображений алгоритм індивідуальної імунопрофрілактики з використанням сучасних методів достовірного прогнозування ризиків і небезпеки вакцинації.

Ключові слова: імунопрофрілактика інфрекцій, вакцини, ризики вакцинації, доцільність вакцинації, поствакцинні ускладнення, прогнозування ускладнень вакцинації, алгоритм індивідуальної вакцинації.

Більше трьох тисяч років тому, коли в Китаї зародилися перші основи вакцинації, шляхом прищеплення вмісту пухирців від хворих на натуральну віспу здоровим, людство почало активно боротися з інфекційними і паразитарними хворобами. Потім цей спосіб був використаний в Азії, Індії і значно пізніше - в Європі. Проте реальне емпірично обґрунтоване практичне застосування вакцинації в медицині почалося Едвардом Дженнером лише наприкінці 18 ст., коли в 1796 р. вмістом пустул хворої на коров'ячу віспу жінки був уперше успішно щеплений 8-річний хлопчик [1, 2]. Але тільки майже через століття, у кінці 19-го - початку 20-го ст., на основі активного розвитку і досягнень мікробіології, імунології та медицини (дослідження Р. Коха, Л. Пастеpa, I.I. Мечникова) були закладені наукові основи створення вакцин, вакцинації та пасивної імунопрофрілактики інсрекційних хвороб [2, 3]. Саме з того часу і почалося усвідомлене науково обґрунтоване використання імунопрофрілактики інфекцій, яке активно триває й розробляється і сьогодні. Але, незважаючи на сучасний розвиток науки і медицини, інсрекційні хвороби були і залишаються однією 3 найбільш актуальних проблем людства. Яскравим прикладом цього може бути 7-а 
пандемія холери, що виникла ще в 1961 р. і триває досі. Ïї особливістю $€$ те, що збудник, потрапивши на яку-небудь територію, більше не покидає ії, незважаючи на проведення активних та інтенсивних протиепідемічних заходів [4]. Невирішеними на сьогодні залишаються проблеми захворюваності й поширення грипу, малярії, туберкульозу, ВІЛ-інфекції/СНІДу, вірусних гепатитів, геморагічних гарячок і ряду інших інфекційних хвороб. До відомих нам інфекцій за останні десятиліття приєдналися раніше невідомі нові інфекційні хвороби людини (гепатити C, D, E, G, мавпяча віспа, хвороба Зіка, пріонові хвороби та ін.). Не відстають від них і «старі» інфрекції, збудники яких активно еволюціонують, закономірно змінюючи епідеміологію, патогенез і клініку хвороб, а також змінюючи арсенал і підходи до їх етіотропної терапії. Ера бактерійних інфекцій, після відкриття в 40-х роках 20-го століття антибіотиків та їх широкого практичного використання, хоч і не здає своїх позицій остаточно, проте закономірно і неухильно змінюється ерою вірусних і паразитарних хвороб. Міняється також і людина з їі патологією. У світі, що нестримно змінюється, і несприятливому довкіллі з їх екологічними проблемами, масовим вимушеним споживанням людьми генетично модифрікованих, насичених антибіотиками, гормонами, штучними токсичними та імуноактивними харчовими добавками і консервантами харчових продуктів, широким і не контрольованим використанням у лікувальній практиці антибіотиків, противірусних і гормональних препаратів, імунокоректорів і хіміотерапії, одну з провідних ролей в патології людини зайняла імунопатологія (як імуносупресивні, так і алергічні й автоімунні хвороби). Разом з еволюцією патогенних і вірулентних мікроорганізмів, зміна імунореактивності людей і значне зростання числа хворих з патологією імунної системи зіграла одну з провідних ролей у виникненні серйозних проблем та істотних змін у специфрічній імунопрофрілактиці інфекційних і паразитарних хвороб.

ще декілька десятиліть тому практично не було проблеми зниження специфічного імунітету після проведення повного курсу вакцинації і такий набутий імунітет виправдано вважався фрактично вже «довічним» або все ж припускав за необхідності досить тривалий період до ревакцинації. Сьогодні усе кардинально змінилося. Більше не говорять про «довічний» імунітет, цей термін правомірно замінений на «стійкий», що повністю відповідає сучасним реаліям. На жаль, це стосується не лише поствакцинного імунітету, але й імунітету після перенесеного інфекційного захворювання! Постійно і досить часто змінюються «календарі» щеплень, змінюються режими й дози вакцинації (у тому числі і самі вакцини), i, що найважливіше, вводяться нові режими, які припускають частішу ревакцинацію, скорочення періоду між вакцинацією і ревакцинаціями, а також вимагають ревакцинацію навіть в осіб похилого віку. Усе це безпосередньо свідчить про істотне зниження ефективності класичної і традиційної вакцинації, а також про тотальне зниження популяційного імунітету людей. Передусім це стосується країн з високим рівнем урбанізації, розвиненим промисловим сектором і наявністю екологічних проблем.

Не є винятком і так звані «керовані» інфекції, епідемічний процес яких раніше досить ефективно керувався за допомогою масової імунопроорілактики, в першу чергу вакцинації, та активних протиепідемічних заходів. Але втручання людини в природний перебіг епідемічного процесу багатьох, у тому числі й «керованих» інфекцій, змогло внести до нього тільки деякі тимчасові корективи, але повністю й кардинально його змінити не змогло, що було передбачене і доведене ще в середині минулого століття академіком Л.В. Громашевським у створеному ним вченні про епідемічний процес. Це безпосередньо пов'язано з циклічністю і саморегуляцією в системі збудник-сприйнятливий організм у певному тимчасовому інтервалі, що було показано В.Д. Беляковим із співавт. у 70-х рр. 20-го ст. [5].

Незважаючи на істотний прогрес в галузі імунопрофрілактики інфекційних хвороб, сьогодні ми можемо реально «керувати» (активно запобігати за допомогою імунопрофрілактики - вакцинації) усього лише 30, із понад 1500 відомих нам інфекцій [6-8]. Очевидно - результат дуже скромний. Єдиним реальним досягненням можна вважати перемогу над натуральною віспою, яка, за даними ВООЗ, була повністю ліквідована в 1980 р. (останній випадок віспи був зареєстрований в 1977 р. у Сомалі) і вакцинація від віспи була припинена. Але слід пам'ятати, що зразки життєздатного вірусу (сьогодні віруси зараховані до «живих» [9]) зберігаються у двох наукових лабораторіях (репозиторіях) світу - у США (CDC, Атланта) і Росії (Державний науковий центр вірусології і біотехнології «Вектор», Новосибірськ) $[10,11]$. У ліквідації ж інших інфекцій людство поки що не досягло реальних успіхів.

Проте імунопрофрілактика й сьогодні $€$ фрактично єдиним дієвим засобом стримування і поширення інфрекційних хвороб. Про її користь і шкоду ведуться суперечки вже не одне десятиліття, але реальної альтернативи на сьогодні їй немає. Використання вакцин дійсно відчутно змінило природний перебіг епідемічного процесу інфекцій, стосовно яких проводиться активна імунопрофрілактика. Саме імунопрофрілактика змогла забезпечити реальне та істотне зниження рівня захворюваності на ці інфекції, аж до одиничних випадків, значно знизити їх поширеність і найголовніше - практично звести до нуля випадки інвалідизації та смертнос- 
ті від цих інфекційних захворювань. Такі досягнення сучасної імунопроорілактики виправдано дозволили назвати ті інорекції, відносно яких проведена активна й масова вакцинація, а також активні протиепідемічні заходи виявилися досить ефективними - «керованими інфекціями». Як приклад успіху людини в боротьбі 3 інфекціями можна навести такі керовані інфекції, як поліомієліт, дифтерію, кір, кашлюк, краснуху. $€$ надія на появу нових керованих інфрекцій, таких як HBV-інфрекція, онкогенних представників HPV-інфекції, окремих геморагічних гарячок.

Але ці успіхи виявилися все ж тимчасовими. Тож інфрекції, відносно яких проводиться імунопрофілактика (вакцинація), сьогодні тільки умовно можна назвати «керованими». Закономірні зміни збудників інсрекцій і людини в сучасних умовах призвели до того, що вакцинація сьогодні не завжди може забезпечити реальний індивідуальний, а в деяких випадках і колективний специфічний імунітет від інфрекції, а отже не завжди може забезпечити й індивідуальний і колективний захист від керованої інфекції, відносно якої проводиться імунопрофрілактика. Дуже лаконічно й досить точно це було ссрормульовано в одному з досліджень: «поняття стану «вакцинований» та «імунний» з одного боку і «захищений» - 3 другого, не завжди збігаються» [12]. Крім цього, навіть наявність у крові людини захисного рівня специфрічних для цієї інфрекції антитіл (за яким і судять про наявність імунного захисту) не завжди гарантує захист, і такі особи можуть переносити інорекцію, до якої вони мають імунітет?! I якщо, дійсно, вакцинація не завжди і з різних причин (неякісні вакцини, недотримання режимів зберігання якісних вакцин, недотримання доз і режимів вакцинації та ревакцинації, індивідуальні стани імуносупресії вакцинованої особи) не завжди може приводити до формування специфрічного імунітету, то чому за наявності імунного захисту розвивається інфекційне захворювання? Якщо виключити помилку лабораторної діагностики, то єдиним поясненням буде те, що імунітет у цієї особи не такий вже і «специфічний» до сучасного збудника або ж на момент інфікування цього імунітету взагалі могло не бути на тлі розвинутого імунодефіциту (навіть тимчасового, наприклад, пов'язаного із застосуванням імунодепресантів). Крім цього, існуюча досі оцінка рівня й активності поствакцинного імунітету за рівнем специфрічних сироваткових IgG до вакцинних антигенів не може повною мірою відобразити реальну картину специфрічного імунного захисту, особливо при вірусних інсрекціях, де основну роль відіграє усе ж не гуморальний, а клітинний імунітет, а циркулюючі в крові «успішно» вакцинованої людини специфічні антитіла, або не мають нейтралізуючих властивостей відносно збудника, або вони істотно зни- жені. У цій ситуації також необхідно враховувати і той варіант формування специфічного постщепного імунітету, коли при активному формуванні його гуморальної ланки, на рівні клітинної ланки має місце її імунна недостатність, можливо, пов'язана з індивідуальними, генетично обумовленими особливостями такого типу відповіді конкретної людини на конкретну вакцину або конкретного збудника інфрекції.

Також у сучасних умовах не можна скидати з рахунків і можливість фрормування у конкретної людини стану повної або часткової імунної толерантності (тимчасової або постійної) до компонент конкретної вакцини або також до конкретного збудника інфекційної хвороби. У такій ситуації відносно інших вакцин та інсрекцій у конкретних осіб має місце повноцінна імунна реакція.

Таким чином, імунодесріцити та імунна толерантність нерідко призводять до низької ефективності або взагалі відсутності ефекту від імунопрофрілактики. Саме 3 цим і можуть бути пов'язані можливі варіанти індивідуальних «невдач» при вакцинації окремих осіб, вже фрактично об'єктивно незалежні ні від якості вакцин, ні від режимів їх застосування. Також наведені дані показують, що сьогодні при досить широких можливостях лабораторної діагностики потрібне істотне розширення оцінних якісних і кількісних показників, параметрів і тестів для об'єктивної оцінки фрормування поствакцинного імунного захисту. Але, на жаль, якихось або «нових» показників, способів і методів реальної практичної оцінки напруженості індивідуального і популяційного (колективного) імунітету, крім визначення рівня специорічних («захисних») антитіл на сьогодні в практиці охорони здоров'я ні у нас, ні за кордоном фрактично немає. Умовно «новими» можна назвати методи, що пропонують одноразове i/або динамічне (у часі після вакцинації) визначення рівня або титру все тих же захисних антитіл [12-14]. Фактично і по суті крім тимчасової динаміки змінюються деякі методичні підходи до визначення рівня специсрічних імуноглобулінів замість РПГА або РНГА (реакція пасивної або непрямої гемаглютинації), РГГА (реакція гальмування гемаглютинації) і $\mathrm{PH}$ (реакція нейтралізації (для вірусних вакцин) сьогодні часто використовують ІФА (імунофрементний аналіз), а також імунохемілюмінесцентний аналіз, що поступово приходить йому на зміну. Дійсно ІФА сьогодні вже став рутинним і стандартним методом якісних і кількісних досліджень наявності і рівня специфрічних імуноглобулінів різних класів ( $\lg$ M, G, A, E та ін.), що обчислюються сьогодні в уніфікованому стандарті у вигляді МО/мл. Це дає можливість стандартизувати результати досліджень і поступово замінити «старі» методи (РНГА, РПГА, РГГА, $\mathrm{PH})$, результати, що у вигляді титрів (розведень початкової сироватки), які складно стандартизувати і де ре- 
альний захисний рівень антитіл безпосередньо залежить від активності діагностикуму, а, отже, при одному і тому ж титрі сироватки реальний рівень антитіл, виражений в МО/мл може значно різнитися, що вимагає використання спеціальних таблиць порівняння і перерахунку. Це може призводити до серйозної плутанини інтерпретацій результатів дослідження [15-18]. Але, незважаючи на це, разом з ІФА сьогодні для оцінки рівня напруженості специфічного імунітету також офріційно продовжують використовуватися старі класичні методи дослідження у вигляді РНГА/РПГА, РГГА, РН та ін. Також, на превеликий жаль, в Україні досі немає жодної «референс» або «контрольної» лабораторії, де ці дослідження були б чітко стандартизовані, а їх результати мали б максимальний рівень достовірності. Тому на практиці доводиться використовувати вказаний вище арсенал засобів імунодіагностики. Він дуже розрізнений і основна маса досліджень пропонується й виконується в основному комерційними лабораторіями, де врахувати реальну якість діагностичних тест-систем, устаткування та якості роботи персоналу украй складно. Але доводиться задовольнятися й цим, оскільки можливості державних і комунальних медичних установ у плані імунодіагностики напруженості специфічного імунітету сьогодні украй обмежені. У кращому разі вони можуть виконати лише якісні дослідження просто на наявність специфрічних антитіл, що абсолютно недостатньо для достовірної оцінки рівня імунного захисту.

Проблемами вакцинації в нашій країні займаються різні фрахівці. В основному це педіатри і сьогодні вже «сімейні лікарі», що забезпечують проведення імунопросрілактики дітям, згідно із затвердженим МОЗ України «Календарем щеплень». Але також за необхідності цим займаються терапевти, хірурги, травматологи (у тому числі й рабіологи), інфекціоністи і представники інших медичних спеціальностей. Таким чином, до імунопрофрілактики причетний дуже широкий спектр фахівців, які використовують імунопрофілактику тільки час від часу. Не усі з них мають необхідні знання, що стосуються імунопрофрілактики (вакцинації) i, як правило, керуються на практиці тільки існуючими нормативними документами у вигляді затверджених офріційних галузевих наказів, стандартів (протоколів) та інструкцій до вакцин. У більшості цих лікарів немає достатнього досвіду проведення вакцинації, необхідних знань ії особливостей, оцінки необхідності, доцільності, побічних ефректів і ускладнень вакцинації і, найголовніше, - знань у галузі реальної оцінки протипоказань і небезпеки імунопрофрілактики в конкретної людини. Чи $є$ у нас фрахівці, обов'язком яких і $€$ вирішення вказаних проблем? Чи займаються вони реально саме цими проблемами?
Відповідь дуже проста. У реєстрі лікарських спеціальностей, затверджених МОЗ України, вже багато років $€$ такі клінічні практичні спеціальності як: «Дитяча імунологія»; «Імунологія»; «Клінічна імунологія» [19]. Саме їх представники й повинні вирішувати проблеми вакцинації як для окремих осіб, так і при масовій імунопрофрілактиці. Але на практиці сьогодні це перекладається на плечі «багатоверстатника» - сімейного лікаря, який не може мати спеціальних і глибоких знань у питаннях імунодіагностики та імунопрофрілактики. Це не закладено в програмах його навчання, підготовки, перепідготовки і програмах післядипломної освіти й підвищення кваліфікації. Можна справедливо заперечити, що це не так. Так, дійсно ці проблеми мають віддзеркалення у вказаних вище програмах, але саме «віддзеркалення», а не достатні за об'ємом і часом розділи, присвячені проблемам клінічної практичної імунології. Саме тому проблемами імунопрофрілактики й повинні займатися фахівці з клінічної імунології або лікарі найбільш близьких до них спеціальностей - алергологи та інорекціоністи (передусім дитячі), які мають для цього спеціальні знання і навички. Але реально на практиці «імунологи» проблемами вакцинації займаються, як правило, як «виняток». Широке використання імунопрофрілактики в клінічній роботі «імунолога» навіть сьогодні фрактично не практикується, хоча за фрактом це його безпосередня робота, оскільки більш підготовлених фрахівців з усього переліку номенклатури лікарських спеціальностей (на сьогодні їх 124!) просто немає. Крім цього, навіть у великих і структурно розвинених містах України фрахівців «імунологів» у медичному секторі - одиниці. Вони просто не передбачені штатним розкладом у більшості лікувальних установ, а в «Центрах первинної медичної (медико-санітарною) допомоги» (які сьогодні в ракурсі здійснюваної рефрорми $€$ «провідною» $\mathrm{i}$ «оловною» ланкою вітчизняної медицини) і його структурних підрозділах - взагалі відсутні! [20]. При реорганізації «Санітарної служби України» (фрактично її ліквідації) її приймачі у вигляді «Держспоживслужби» та Державні установи «Обласні лабораторні центри МОЗ України» хоча й мають у своїй структурі «Відділ санітарно-епідеміологічного нагляду та організації розслідування спалахів», по суті, втратили реальну функцію «старих» епідеміологічних відділів санітарно-епідеміологічних станцій, які реально займалися імунопрофрілактикою.

Виходячи $з$ наведеного, очевидно, що $з$ медичних фрахівців займатися проблемами індивідуальної імунопрофрілактики при її масовій реалізації - фрактично нікому. Але фрормальні обов'язки в цій сфрері медичні фрахівці все ж вимушено реалізують. Але це саме фрормальні обов'язки і проблеми індивідуальної імунопрофілактики лягають на самих же пацієнтів, які не в змозі самостійно 
або, навіть, за допомогою комерційних медичних структур розв'язати цю проблему, що вимагає системних, продуманих, кваліфікованих і обґрунтованих рішень саме на державному рівні, оскільки саме на державу і покладено завдання (це ії один з основних обов'язків) захисту населення від інфекційних і паразитарних хвороб і запобігання їх епідеміям [21, 22]. Але, на жаль, сьогодні держава 3 цією проблемою не справляється і вирішувати ії доводиться громадянам фрактично самостійно, особливо в плані захисту від побічних ефектів, ускладнень і смертей при проведенні масової й активної вакцинації!

Сьогодні в Україні, згідно з останніми даними, може бути проведена вакцинація від 26 іноекцій. Використовувані для цього вакцини можна розділити на «обов'язкові» (вакцинація за віком), які включені в національні календарі щеплень (вони відрізняються в різних країнах за наборами «керованих» інфекцій і режимах проведення вакцинації), ті, які застосовують за станом здоров'я» (для пацієнтів з високим ризиком і тяжким перебігом інфекцій, вакцин для імунопрофрілактики яких немає в календарі щеплень), «рекомендовані вакцини» (для окремих груп осіб) і вакцини, використовувані за «епідемічними показаннями» [23-25]. Так, в український календар щеплень включено усього лише 10 вакцин від керованих інсрекцій: туберкульозу; гепатиту В; кору; епідемічного паротиту; краснухи; диотерії; правця; коклюшу; поліомієліту і гемофрільної інфрекції типу В. Після проведення повного курсу вакцинації тільки для дисртерії і правця у дорослих передбачені і рекомендовані ревакцинації кожні 10 років після останнього щеплення в 16 років. У вказаних вище джерелах передбачена вакцинація і окремих груп осіб: «Вакцинація дітей з порушенням Календаря»; «Вакцинація ВІЛ-інорікованих осіб»; «Вакцинація за станом здоров'я»; «Вакцинація пацієнтів після алло/автотрансплантації стовбурових клітин». У цих групах окрім «обов'язкової» імунопрофрілактики може бути рекомендована вакцинація (без дублювання вакцин з інших груп) від грипу, пневмококової, менінгококової інфекції і гепатиту А.

До групи «рекомендованих вакцин» (без дублювання вакцин з інших груп) входять препарати від: вітряної віспи, папіломавірусної інфекції і ротавірусної інсрекції. Також, украй важливо, в цьому розділі передбачена можливість вакцинації для дітей і дорослих (крім вказаних вище вакцин) від «захворювань, для імунопрофілактики яких є вакцина, зареєстрована в Україні».

І в групу за «епідемічними показаннями» в окремому розділі «Вакцинації, які проводяться на ендемічних та ензоотичних територіях і за епідемічними показаннями» наведений додатковий перелік вакцин і рекомендацій з вакцинації від: туляремії; гарячки Ку; бруцельозу; кліщового енцефаліту; чуми; черевного тифу; грипу; жовтої гарячки; сказу; дифртерії; правця; гепатиту А; кору; епідемічного паротиту; поліомієліту; краснухи; менінгококової інфекції; гепатиту В; сибірки; вітряної віспи; кашлюку (21 захворювання). Без дублювання вакцин 3 інших груп це вакцини від: туляремії, бруцельозу, гарячки Ку, кліщового енцефаліту, чуми, черевного тифу, жовтої гарячки, сказу і сибірки [23-25]. Для кожної вакцини є власний режим застосування і ревакцинації. I це істотно ускладнює завдання безпеки такої імунопрофрілактики.

Не можна не відзначити дуже цікавий фракт у нормативній базі нашої медицини. Так, в діючому наказі МО3 України № 551 від 11.08.2014 р. «Про удосконалення проведення профілактичних щеплень в Україні» $€$ дуже важлива, але украй суперечлива частина документу (розділ II. «Порядок проведення щеплень» частина 2. «Щеплення дітей з порушенням Календаря»), в якій прямо вказано, що за необхідності (яка ця необхідність, не повідомляється!) далі дослівно: «За потреби лікар має право ввести всі вакцини/анатоксини, що показані за цим Календарем (крім БЦЖ), за одне відвідування особою закладу охорони здоров'я. Ін'єкції можна робити в різні ділянки тіла за умови, що це не суперечить інструкції про застосування конкретної вакцини/анатоксину. В іншому випадку лікар планує такі щеплення з урахуванням мінімальних інтервалів між введенням вакцин/анатоксинів». І такі рекомендації дані на фроні украй високого рівня антигенного і фрармакологічного навантаження людей, високого рівня алергізації населення, а також його украй негативного ставлення до вакцинації. Проте, навіть з позиції здорового глузду обивателя, така необхідність може бути тільки крайньою необхідністю, за межею якої без «необхідної» комплексної імунопрофрілактики є украй високий ризик розвитку тяжкої інорекції з високим рівнем летальності! Але про це в зазначеному наказі нічого не повідомляється, а це ілюзорне «право» для лікаря, фрактично нічого не означає в плані його юридичного захисту у разі розвитку ускладнень при вказаній «необхідній» вакцинації. По суті таке «право» без чітких вказівок критеріїв «необхідності» для пацієнта несе тільки реальні додаткові ризики з високою вірогідністю розвитку серйозних і тяжких поствакцинних ускладнень при такій комплексній вакцинації!

Але нині в країні, де практично у більшості людей мають місце порушення режимів вакцинації за «Календарем щеплень», таке «право» для реалізації «необхідності» таїть у собі відверті небезпеки для людини, яка вакцинується! Порушення «Календаря щеплень» реалізується або у вигляді відсутності вакцинації окремими вакцинами, або проведенням її неповного курсу, що призводить до відсутності або недостатнього рівня від- 
повідного специфічного імунітету. Це робить вакцинацію не просто необхідною, а в деяких випадках навіть обов'язковою і життєво необхідною. 3 другого боку, високий рівень алергізації населення приховує високий ризик серйозних і тяжких ускладнень, які, на жаль, нерідкі при вакцинації, навіть у разі високої якості самих вакцин і повного дотримання режимів їх транспортування, зберігання і застосування. У цій ситуації особливо важливо, що при проведенні передусім масової вакцинації завжди матимуть місце тяжкі ускладнення, розвиток так званих «вакцинних» інфекцій і, навіть, випадки смерті, безпосередньо пов'язані із застосуванням вакцин (часто це анафілактичні реакції). Рівень таких ускладнень i, особливо, летальних випадків украй малий i, за офріційними даними, не перевищує 0,001-0,01 випадку на 1000 вакцинованих [6, 7, 26, 27].

Але якщо розглядати таке незначне число поствакцинних побічних ефектів, ускладнень і, навіть, смертей у ракурсі масової імунізації, результатом якої $є$ фрормування колективного або популяційного специфічного імунітету, що у свою чергу веде до різкого спаду захворюваності (до одиничних окремих випадків) конкретними, у тому числі й тяжкими інфекціями з високим ризиком смертності, а також робить ці інфекції керованими і запобігає їх епідемії, то з точки зору популяції і статистики це - невелика плата за безпеку! На одній із сторінок осріційного сайту ВООЗ дослівно сказано: «І хоча навіть один випадок тяжкої шкоди здоров'ю або смерті в результаті вакцинації - це вже багато, переваги вакцинації значно переважують ризики, і без вакцинації випадків хвороби і смерті було б набагато більше» [28].

I це дійсно так. Пожертвувавши декількома «особинами», ми рятуємо тисячі і мільйони! І це не лише доцільно, але навіть значною мірою гуманно! Що означає декілька смертей порівняно з мільйонами врятованих?! Саме таким твердженням, трансформованим у постулат «колективної безпеки» й обумовлені неодноразові випадки законного юридично обґрунтованого примусу індивідуумів державою до вакцинації! Ілюстрацією цьому є практика і рішення Європейського суду з прав людини, що також визнає у ряді випадків право держави на примус до вакцинації [29]!

Але це тільки з точки зору популяційного або колективного «розуму», якщо розглядати населення як єдиний організм, що складається з окремих особин, які самоорганізовуються, втратили свою індивідуальність. 3 точки зору окремої людини, сім'ї або невеликого колективу втрата їх рідної і близької людини, яка була до цього фрактично абсолютно здоровою, - це горе, непоправна втрата, а також постійне відчуття провини того, що вони не доклали усіх можливих знань, сил і зусиль для запобігання такому результату вакцинації.
Така суперечлива ситуація, коли виникає серйозний конфрлікт інтересів між «популяцією» та «індивідуумом» призводить до того, що, як правило, перемагає «більшість», яка не порівнює навіть втрату індивідуума на догоду своїм інтересам. Але якщо виникає реальна загроза і небезпека для значного числа індивідуумів, така ситуація призводить до того, що вже значна частина популяції приховано або відкрито уникає загрози, закономірно базуючись на звичайному інстинкті самозбереження і використовуючи для цього будь-які засоби. Тепер страждає вже сама популяція. Саме така ситуація і склалася в нашій країні з вакцинацією. Люди почали масово від неї відмовлятися і ніякі засоби держави навіть у вигляді примусу не в змозі це сьогодні змінити. Найяскравіший приклад - епідемія кору з декількома десятками смертей за минулий і 2019 р.

Чи є вирішення цього конфрлікту інтересів. Можна 3 упевненістю стверджувати, що є. Так, воно не абсолютне і абсолютних рішень, на жаль, немає. Але вирішення цієї проблеми досить логічне і просте. Необхідно знайти компроміс між необхідністю разом $з$ доцільністю вакцинації для конкретної людини - з одного боку, а з другого - $з$ максимально можливою (саме індивідуальною!) оцінкою небезпеки такої вакцинації. Вирішення цієї проблеми не зможе повністю виключити ні побічні ефекти, ні ускладнення, ні, навіть, летальні випадки при вакцинації. Але воно спроможне знизити їх до абсолютного мінімуму і найголовніше - дати можливість зрозуміти індивідуумові, що у разі потреби проведення вакцинації йому або його рідним і близьким, будуть враховані й відвернені усі можливі ризики і небезпеки цієї імунопрофрілактики, але не приховуючи того, що абсолютної гарантії безпеки вакцинації все ж немає. Тільки в цьому випадку можна максимально усунути розбіжності на користь колективу і його індивідуумів відносно необхідності проведення масової імунопросрілактики.

Ризик розвитку навіть тяжких поствакцинних реакцій на багато порядків (у тисячі й сотні тисяч разів) менший, ніж вірогідність розвитку тяжких ускладнень і летальності у разі розвитку інфрекційних хвороб (яким запобігає імунопрофрілактика) у невакцинованих осіб. Так, наприклад, при використанні вакцини АКДП тяжкі поствакцинні ускладнення (анасрілактичний шок, енцесралопатія та ін.) можуть розвиватися в 0,001-0,005 випадку на 1000 вакцинованих, але у разі розвитку в людини дифтерії, правця і коклюшу вірогідність смертності при них може досягати рівня 5, 20 і 0,125 \% відповідно! Ризик розвитку поствакцинних паралічів і вакциноасоційованого поліомієліту при вакцинації живою оральною поліомієлітною полівалентною вакциною може досягати 0,0003-0,00133 випадку на 1000 вакцинованих, але в той же час рівень смертності і в'ялих паралічів при поліомієліті може до- 
сягати відповідно 0,5-1 (до 50-300 при паралітичній фрормі) і 10 осіб на 1000 хворих. При використанні живої корової вакцини вірогідність розвитку енцефраломієліту становить 0,001 випадку на 1000 щеплених, а при захворюванні кором ризик його виникнення може підвищуватися до 4-6 випадків на 1000 хворих. Стає очевидною абсолютна непорівнянність ризиків від вакцинації та розвитком тяжких ускладнень і смерті від інфекцій, відносно яких і здійснюється вакцинація. I це далеко не повний перелік її переваг.

Дійсно, ризики вакцинації, навіть 3 тяжкими наслідками, мінімальні, але все таки варто нагадати, що нехай і за мізерною кількістю ризиків вакцинації стоять здоров'я і життя реальних людей, безпека яких відповідно до головного принципу медицини «Не нашкодь» - має бути головною і пріоритетною умовою при проведенні імунопрофрілактики. У цьому зв'язку зазначимо, що поствакцинні реакції можна умовно розділити: на власне «поствакцинні» - які не становлять особливої загрози, зникають самостійно протягом короткого часу і не призводять до стійкого погіршення здоров'я і «поствакцинні ускладнення» - стійкі порушення здоров'я, нерідко з тяжким перебігом і, навіть, можуть закінчуватися смертю. У нашому дослідженні розглядаються тільки «поствакцинні ускладнення», які у свою чергу необхідно розділити на «очікувані» й «непередбачені», а також за ступенем їх тяжкості. Відразу ж виділимо 3 цієї групи саме «тяжкі непередбачені ускладнення» у вакцинованих, до яких необхідно віднести: смерть; ускладнення, що становлять загрозу для життя; ускладнення, що вимагають тривалої госпіталізації; значне і стійке порушення здоров'я; внутрішньоутробні аномалії і вади розвитку плода або дитини, що народилася від матері, в якої проведена вакцинація. До клінічних проявів і варіантів таких ускладнень слід віднести: алергічні реакції негайного типу у вигляді анафрілактичних реакцій і анафрілактичного шоку; тяжкі генералізовані алергічні реакції (негайного та сповільненого типів) у вигляді ангіоневротичного набряку, синдромів Лайєла, Стівенса-Джонсона, сироваткової хвороби, алергічних та автоімунних енцефаломієлітів і поліневритів; генералізованих інорекцій, зумовлених вакцинними штамами мікроорганізмів (дуже показові вакцина БЦЖ, оральна поліомієлітна вакцина і корова вакцина); ураження центральної нервової системи, пов'язані з використанням живих вакцин у вигляді вакциноасоційованих енцефаліту, менінгоенцефалітів, енцефаломієлітів, невритів і поліневритів (оральна поліомієлітна вакцина, корова вакцина і вакцина від вітряної віспи), артритів (вакцина проти краснухи) та ін. [6, 7, 26, 27].

Наведений широкий спектр серйозних і тяжких ускладнень вакцинації показує насущну необхідність індивідуального прогнозування «непрогнозованих поствакцинних ускладнень» 3 логічним наступним запобіганням їм і профілактикою, що дасть можливість індивідуального прогнозу розвитку поствакцинних ускладнень, а отже дозволить максимально їх скоротити. Саме такий підхід зможе вирішити описаний конорлікт інтересів між колективом (державою) та індивідуумом і забезпечити максимальний захист від керованих інфекцій для обох сторін.

Це рішення лежить на поверхні й нічого нового в цьому немає! Недаремно говорять, що: «Нове - це добре забуте старе». Спроби системно розв'язати проблему на державному рівні вже давно робилися ще наприкінці 80-х, початку 90-х років минулого століття в тодішньому СРСР і вже на пострадянському просторі, у тому числі й в Україні.

Передусім, зіткнувшись 3 проблемою необхідності проведення індивідуальної вакцинації або ревакцинації, необхідно було оцінити доцільність ії̈ проведення. Така оцінка була розроблена на вже наявній базі оцінки напруженості постінфекційного і поствакцинного імунітету і відображена в нормативних документах, у тому числі й ВОО3, у вигляді мінімального захисного рівня специфічних антитіл. Така інфрормація сьогодні міститься не лише в офріційних нормативних документах органів охорони здоров'я, але й в інструкціях із застосування деяких вакцин і, навіть, в інструкціях до ІФА тест-систем для визначення рівня специфічних антитіл [30]. Крім цього, в зазначених документах можуть бути вказані рекомендації відносно вакцинації і/ або ревакцинації відповідно до рівня цих антитіл. Під керівництвом ВООЗ у практиці оцінки ефективності імунопрофрілактики було прийнято уніфіковане вираження рівня (концентрації) специорічних захисних антитіл у вигляді Міжнародних одиниць (МО) на мілілітр (МО/мл) рідше на літр (МО/л) і використання як метод дослідження ІФА (його різних модисрікацій). Це стало можливим, коли ВООЗ прийняло міжнародні стандарти зразків сироваток до різних збудників інфекцій і дало можливість ввести в лабораторну практику об'єктивну оцінку порівняння результатів кількісного визначення рівня специфічних антитіл при використанні тестсистем різних виробників [31-33]. Але в інструкціях різних виробників ІФА тест-систем, незважаючи на їх стандартизацію та універсальність, може бути вказаний «свій» «оригінальний» рівень специфрічних захисних антитіл, як правило, близький, але все ж відмінний від показника, вказаного в офіційних нормативних, у тому числі й міжнародних, документах. Тому цю особливість необхідно обов'язково враховувати особливо при оцінці індивідуальних показників, близьких до мінімального захисного рівня. 


\section{ДИСКУСІї ТА РОЗДУМИ}

Крім цього, незважаючи на стандартизацію та уніфрікацію досліджень рівнів захисних антитіл, досі використовуються РНГА/РПГА, РГГА, РН та ін., результат яких виражений в «титрах» активності досліджуваних сироваток крові. Також слід зазначити, що реальний один і той же рівень захисних антитіл, але виражений в титрах, наприклад для визначення рівня антитіл для дистерії і/або правця в РПГА/РНГА, може відповідати різним титрам (різниця може бути дуже значною!), що залежить від активності еритроцитарного діагностикуму набору для РНГА! Тому для усунення цих відмінностей використовують спеціальні таблиці перерахун- ку титрів в МО/мл, згідно з міжнародними стандартами [15-18].

Так, при оцінці напруженості імунітету до дифтерії та правця практично в усіх інорормаційних джерелах і сучасних нормативних документах наведені дані про мінімальний захисний рівень антитоксичних протидифтерійних антитіл, який визначений на рівні 0,1 МО/мл. Але цей рівень при використанні РНГА/РПГА може відповідати абсолютно різним титрам, що безпосередньо залежить від активності еритроцитарного діагностикуму. Це відображено в наведеній нижче офріційній таблиці перерахунку (табл. 1) [15-18].

Таблиця 1

Залежність рівня антитоксичних антитіл, вираженого в МО/мл, від активності діагностикумів у РПГА/РНГА

\begin{tabular}{|c|c|c|c|c|c|c|}
\hline \multirow{3}{*}{$\begin{array}{c}\text { Титр } \\
\text { досліджуваної } \\
\text { сироватки }\end{array}$} & \multicolumn{6}{|c|}{ Концентрація антитоксичних антитіл в МО/мл } \\
\hline & \multicolumn{3}{|c|}{$\begin{array}{c}\text { Активність дисртерійного діагностикуму } \\
\text { титр/МО/мл }\end{array}$} & \multicolumn{3}{|c|}{$\begin{array}{c}\text { Активність правцевого діагностикуму } \\
\text { титр/МО/мл }\end{array}$} \\
\hline & $1: 3200 / 0,003$ & 1:6400/0,00156 & 1:12800/0,0007 & 1:1280/0,003 & $1: 2560 / 0,00156$ & 1:5120/0,0008 \\
\hline $1: 10$ & 0,03 & 0,015 & 0,0075 & 0,03 & 0,015 & 0,0075 \\
\hline $1: 20$ & 0,06 & 0,03 & 0,015 & 0,06 & 0,03 & 0,015 \\
\hline $1: 40$ & 0,125 & 0,06 & 0,03 & 0,125 & 0,06 & 0,03 \\
\hline $1: 80$ & 0,25 & 0,125 & 0,06 & 0,25 & 0,125 & 0,06 \\
\hline $1: 160$ & 0,5 & 0,25 & 0,125 & 0,5 & 0,25 & 0,125 \\
\hline $1: 320$ & 1 & 0,5 & 0,25 & 1 & 0,5 & 0,25 \\
\hline $1: 640$ & 2 & 1 & 0,5 & 2 & 1 & 0,5 \\
\hline $1: 1280$ & 4 & 2 & 1 & 4 & 2 & 1 \\
\hline $1: 2560$ & 8 & 4 & 2 & 8 & 4 & 2 \\
\hline $1: 5120$ & 16 & 8 & 4 & 16 & 8 & 4 \\
\hline $1: 10240$ & 32 & 16 & 8 & 32 & 16 & 8 \\
\hline $1: 20480$ & 64 & 32 & 16 & 64 & 32 & 16 \\
\hline
\end{tabular}

У таблиці 2 наведені дані про захисний рівень специсрічних антитіл для окремих керованих інсрекцій [7, 30, 34-50]. Зазначені в таблиці дані ілюструють те, що не для усіх керованих інфекцій на сьогодні чітко визначені мінімальні захисні рівні антитіл (кір, кашлюк, епідемічний паротит, краснуха) і вони наведені у вигляді інтервалів. Швидше за все така ситуація обумовлена використанням різних методичних підходів для комплексної оцінки показників гуморальної і клітинної ланок специфрічного імунітету при різних інфрекціях [36, 45-50].

Незважаючи на стандартизацію і використання міжнародних стандартів, досі зберігаються деякі відмінності в оцінці мінімального захисного рівня сироваткових антитіл. Так, мінімальним рівнем протиправцевих антитіл, який вважається захисним, як і у разі дисртерії, є концентрація специфрічних антитоксичних антитіл у сироватці крові, рівна 0,1 МО/мл [15-18]. Проте тільки в наказі МО3 України №198 від 05.08.1999 р. «Про вдосконалення профрілактики, діагностики та лікування правця», який і на сьогодні має статус діючого, є істотне уточнення. А саме цей рівень антитіл 0,1 MO/мл вважається захисним, якщо він визначений в реакції нейтралізації (РН)! Для РПГА/РНГА захисним рівнем вважається не 0,1 МО/мл, а 0,5 МО/мл! Але в більшості інфрормаційних джерел цих даних немає і єдиним показником захисту вказується саме 0,1 MO/мл, що має істотне значення, оскільки в більшості випадків для визначення рівня антитоксичного імунітету відносно правця використовують не $\mathrm{PH}$, а простішу, стандартизовану і доступну РНГА/РПГА. Таким чином, визначення рівня анти- 


\section{ДИСКУСІї ТА РОЗДУМИ}

тіл до правцевого токсину в РПГА/РНГА рівних 0,1 МО/ мл, навіть з урахуванням активності еритроцитарних діагностикумів (при 1:1280, 1:2560 і 1:5120) і використанням спеціальних таблиць, які наведені практично в усіх інформаційних джерелах, в реальності маємо рівень антитіл в 4-5 разів нижчий від мінімального захисного рівня! На це необхідно звернути особливу увагу, що й наголошено у відповідному наказі МОЗ України (№198 від 05.08.1999 р.). У ньому чітко вказано, що особам 3 ризиком розвитку правця не проводиться навіть екстрена імунопрофрілактика у тому разі, коли рівень захисних протиправцевих антитіл вище 0,1 МО/мл в РН або вище 0,5 МО/мл в РНГА/РПГА [51].

Таблиця 2

Захисний і високий рівень специфрічних антитіл для окремих керованих інфекцій

\begin{tabular}{|c|c|c|c|}
\hline Інфрекція & $\begin{array}{l}\text { Високий захисний титр } \\
\text { антитіл сироватки крові }\end{array}$ & $\begin{array}{c}\text { Мінімальний } \\
\text { захисний рівень } \\
\text { антитіл сироватки крові } \\
\text { (ІФА) }\end{array}$ & $\begin{array}{c}\text { Мінімальний захисний } \\
\text { титр антитіл сироватки } \\
\text { крові }\end{array}$ \\
\hline Туберкульоз & немає даних & немає даних & немає даних \\
\hline Гепатит В & $>1 \mathrm{MO} / \mathrm{M} л$ & $>0,01 \mathrm{MO} / \mathrm{мл}$ & немає даних \\
\hline Kip & $\begin{array}{l}\text { 1:80 РГГА } \\
\text { 1:64 РПГА }\end{array}$ & $\geq 0,15-0,3-0,5 \mathrm{MO} / \mathrm{мл}$ & $\begin{array}{l}\text { 1:4 РГГА } \\
\text { 1:10 РПГА }\end{array}$ \\
\hline Краснуха & 1:320 РГГА & $\geq 10-25 \mathrm{MO} / \mathrm{мл}$ & 1:20 РГГА \\
\hline Епідемічний паротит & 1:80 РПГА & $\begin{array}{l}\geq 0,2 \mathrm{MO} / \mathrm{мл} \\
\geq 0,32 \mathrm{MO} / \mathrm{мл}\end{array}$ & 1:10 РПГА \\
\hline Дисртерія & $\begin{array}{l}\text { 1:640 РПГА } \\
\geq 1 \mathrm{MO/МЛ}\end{array}$ & $\geq 0,1 \mathrm{MO} / \mathrm{мл}$ & 1:40 РПГА \\
\hline Правець & $\begin{array}{l}\text { 1:320 РПГА } \\
\geq 1 \mathrm{MO/МЛ}\end{array}$ & $\geq 0,1 \mathrm{MO} / \mathrm{мл}$ & 1:20 РПГА \\
\hline Поліомієліт & 1:256 РГГА & немає даних & $\begin{array}{l}\text { 1:8 РГГА } \\
\text { 1:16 РН }\end{array}$ \\
\hline Кашлюк & 1:2560 PA & $\begin{array}{l}>0,03 \mathrm{MO} / \mathrm{мл} \\
\geq 0,18 \mathrm{MO} / \mathrm{мл}\end{array}$ & 1:160 PA \\
\hline НIB-інфрекція & немає даних & $\begin{array}{c}\geq 0,15 \text { мкг/мл * } \\
\text { (короткостроковий захист) } \\
\geq 1,0 \text { мкг/мл * } \\
\text { (довгостроковий захист) }\end{array}$ & немає даних \\
\hline Кліщовий енцефраліт & 1:160 РГГА & немає даних & 1:20 РГГА \\
\hline Грип & 1:2560 РГГА & немає даних & 1:40 РГГА \\
\hline
\end{tabular}

Примітки: * - імунотурбідиметрія (замість ІФА); РПГА/РНГА - реакція пасивної/непрямої гемаглютинації; РГГА - реакція гальмування гемаглютинації; $\mathrm{PH}$ - реакція нейтралізації.

Крім цього, згідно з рекомендаціями ВООЗ, існує декілька градацій захисту, залежного від рівня специфрічних антитіл: умовний захист; мінімальний необхідний захист; середній і високий рівні захисту. Так, наприклад, якщо рівень протидифтерійних антитоксичних антитіл знаходиться в межах 0,015-0,06 МО/мл, він може вважатися умовно захисним. Якщо показник становить 0,1 МО/мл - це мінімальний захисний рівень. При показнику в інтервалі від більше 0,1 до 0,5 МО/мл - середній і більше 1,0 МО/мл - рівень захисту вважається високим $[1,7,16,34,52]$. Важливо, що наявність специ- фрічних антитіл, навіть якщо їх рівень не досягає мінімального захисного, вже може вважатися умовним захистом.

Тепер, маючи дані про рівень захисних антитіл, а власне і про ступінь захисту від конкретної інсрекції, слід визначитися з питанням про необхідність і доцільність вакцинації і/або ревакцинації у конкретної людини. Так, при високому рівні захисту (табл. 2) в результаті попередньої вакцинації або перенесеного захворювання, ні вакцинація, ні ревакцинації абсолютно не показані. Мало того, при високому рівні захисних антитіл значно підви- 
щується ризик поствакцинних реакцій і ускладнень [52]! Але не для усіх керованих інорекції $€$ конкретні показники рівня захисних антитіл, при якому високий та украй високий рівень розвитку тяжких поствакцинних реакцій і ускладнень (окремі дані наведені нижче). За відсутності захисних антитіл або їх рівні нижче мінімального захисного (табл. 2) вакцинація або ревакцинація потрібна і показана (з урахуванням протипоказань і можливих поствакцинних ускладнень). При «середньому рівні» захисту вакцинація і ревакцинація недоцільні, але все таки допускаються. У цьому випадку потрібне динамічне спостереження за пацієнтом і у разі зниження рівня захисту вакцинація або ревакцинація можуть стати доцільними, а отже, - можливими або, навіть, необхідними. Часовий інтервал між обстеженнями має бути не менше 6 міс. при показниках захисту близьких до мінімального рівня і не більше 12 міс. при показниках близьких до верхнього показника рівня середнього ступеня захисту. Але тут же слід особливо вказати, якщо показники мінімальних і високих рівнів захисту, як правило, мають офріційно визнані значення, у тому числі й на міжнародному рівні, то показники середнього рівня захисту фрактично не визначені. У мережі Інтернет на web-сайтах окремих лабораторій є дані про рівні захисних антитіл основних керованих інфекцій. Тут же наводяться рекомендації з вакцинації, ревакцинації і, навіть, режими їх застосування. Але ці дані не лише не мають статусу офріційних рекомендацій, але нерідко далекі від них, помилкові й можуть становити реальну загрозу у вигляді тяжких поствакцинних порушень.

Дані таблиці 2 дають інфрормацію не лише про індивідуальну захищеність людини від конкретного інфекційного захворювання. Використовуючи ці дані, також можемо судити і про рівень колективного захисту в популяції. Але в такому випадку ми повинні використовувати емпірично певний рівень імунних до цього захворювання осіб у популяції. Саме показники індивідуального захисту (у вигляді рівня захисних антитіл) і рівня числа імунних осіб (у вигляді відсотка осіб, які мають захисний імунітет) дають нам показник захисту в цій популяції, а отже фактично неможливість розвитку в ній епідемії конкретної керованої інфекції, але спорадичні випадки недуги в цій популяції усе ж можливі. Така комбінація показників і $є$ інтегральним показником колективного імунітету. У таблиці 3 наведені показники колективного імунітету для ряду керованих інорекцій [1, 7, 34, 35, 37-44].

Дані таблиці 3, а саме показник рівня імунних до конкретної інфекції осіб, не слід плутати з рівнем охоплення вакцинацією або просто рівнем щеплених від цієї інфрекції, оскільки ефрективність вакцинації, як правило, далека від 100 \%. Але, навіть при 100 \% числі прищеплених захисний імунітет виробляється не в усіх.
Проте на практиці все ж підміняють показник «рівня імунних осіб» показником «охоплення щепленнями», оскільки оцінити рівень імунітету кожного щепленого дуже складно й економічно недоцільно. Для такої оцінки використовують статистично значущі «вибірки» 3 числа щеплених осіб з розрахунком середнього рівня захисних антитіл.

Для ряду вакцин можливість «керованості» інорекціями досить умовна, оскільки ефективність вакцинації може бути не дуже високою, навіть при використанні найсучасніших і якісних вакцин. Як приклад, можна навести загальновідомі фракти про досить високий рівень захворюваності туберкульозом у щеплених, оскільки, по суті, ця вакцинація запобігає головно тяжкому ступеню туберкульозу і ряду його клінічних варіантів, але не відвертає власне саме інфікування мікобактеріями туберкульозу. Тому, орієнтуючись навіть на об'єктивні показники індивідуального і колективного захисту, не слід забувати про те, що й вони досить умовні та відносні.

Проте, навіть, незважаючи на деякі обмеження, інших об'єктивних показників імунного захисту й ефективності імунопрофрілактики на сьогодні немає. Тому дані таблиці 3 все ж дають об'єктивну інформацію відносно різкого зниження захворюваності та запобігання епідеміям, за наявності вказаного показника рівня імунних осіб із саме захисним рівнем антитіл для наступних інфекцій: гепатиту $\mathrm{B}$, кору, краснухи, епідемічного паротиту, дифртерії, правця, поліомієліту, коклюшу і грипу.

Визначившись на першому етапі з питанням необхідності та доцільності проведення активної індивідуальної імунопрофілактики (в даному випадку вакцинації), на другому - слід вже вирішувати проблему індивідуальних ризиків і небезпеки такої вакцинації. I якщо на першому етапі проблема в основному фактично має способи і засоби для вирішення у вигляді розроблених і науково-обґрунтованих показників рівня імунного захисту, то для другого етапу, при ухваленні рішення про проведення індивідуальної вакцинації, ситуація кардинально протилежна.

Таким чином, можна скласти алгоритм проведення індивідуальної імунопрофрілактики, а саме: спочатку оцінка необхідності конкретної вакцинації за рівнем захисних антитіл (з урахуванням рекомендацій ВООЗ); на другому етапі - оцінка доцільності вакцинації; на третьому етапі, за необхідності і/або доцільності вакцинації - усебічна оцінка можливості специсрічної імунопрофрілактики з урахуванням клінічних протипоказань, а також індивідуальних ризиків, побічних ефректів і небезпеки розвитку алергічних реакцій негайного (рідше сповільненого) типу при використанні у конкретного пацієнта конкретної вакцини. 
Таблиця 3

Показники колективного захисту для деяких керованих інфекцій (у \%)

\begin{tabular}{|l|l|}
\hline $\begin{array}{c}\text { Рівень імунних осіб у популя- } \\
\text { ції, які мають захисний } \\
\text { рівень антитіл }\end{array}$ & \multicolumn{1}{|c|}{ Інорекція } \\
\hline$>90$ & Гепатит В \\
\hline$>93-95$ & Кір \\
\hline$>93-95$ & Краснуха \\
\hline$>90$ & Епідемічний паротит \\
\hline $\begin{array}{l}>95 \text { у дітей } \\
>90 \text { у дорослих }\end{array}$ & Дифтерія \\
\hline $\begin{array}{c}>95 \text { у дітей } \\
>90 \text { у дорослих }\end{array}$ & Правець \\
\hline$>90$ до кожного із серотипів & Поліомієліт \\
\hline$>90$ & Кашлюк \\
\hline $\begin{array}{l}>40-\text { мінімальний } \\
>90-\text { оптимальний }\end{array}$ & Грип \\
\hline
\end{tabular}

Сьогодні в жодній з існуючих в країні лікувальних установ, незалежно від їх фрінансування і виду власності, не проводиться індивідуальна оцінка ризиків і небезпеки використання конкретних вакцин. Правда, потрібно відзначити, що дані першого етапу, а саме показник концентрації специсрічних антитіл, можуть бути використані для оцінки небезпеки вакцинації конкретної людини, але не стосовно конкретної вакцини, а взагалі від цієї інфекції. Такі дані дуже розрізнені й відображені в офріційних документах практично тільки фррагментарно і не для усіх обов'язкових керованих інфекцій. Такі відомості є тільки для дифтерії, правця, кору і кашлюка, але й вони не мають повної уніфрікації. Так, для дисттерії і правця небезпека вакцинації зумовлена високим рівнем захисних антитіл, що становить більше 3,0 і більше 5,0 МО/мл відповідно. Для кашлюка і кору небезпека вакцинації зумовлена рівнем захисних антитіл, що виражений вже у титрах і становить відповідно $\geq 1: 2560$ (у

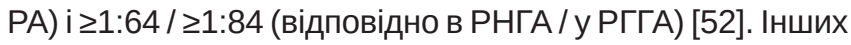
критеріїв оцінки індивідуальних ризиків і небезпеки застосування конкретної вакцини у конкретної людини сьогодні фрактично немає! Але важлива й небезпечна навіть не ця відсутність, її все ж можна заповнити. Украй важливе те, що офріційні органи охорони здоров'я сьогодні навіть не згадують про цю проблему, не кажучи вже про необхідність її невідкладного вирішення. Цю проблему офріційна медицина фрактично просто ігнорує, запропонувавши замість цього сурогатне вирішення у вигляді загальновідомих загальних протипоказань (абсолютних і відносних) до проведення імунопрофілактики $[7,53]$.

Але все-таки раніше ця проблема у вітчизняній офріційній медицині досить широко висвітлювалася і була частково вирішена ще наприкінці 1980-х, початку 1990-х рр. Так, саме в цей час були створені не просто методики оцінки ризику вакцинації, а в широку практику були впроваджені вже комерційні тест-набори для такої оцінки, що дозволяють прогнозувати виражені, тяжкі і серйозні індивідуальні алергічні (реакції негайного і сповільненого типів), у тому числі й анафрілактичні реакції у відповідь на використання конкретних вакцин або їх компонентів. Такий тест-набір був розроблений і випускався науково-виробничою лабораторією «Иммунодиагност» (м. Донецьк) і використовувався на усій території колишнього СРСР, передусім в Україні, оскільки в ній і вироблявся. Цей набір містив антигенні компоненти відразу 6 основних вакцин, а саме: коклюшний, дифтерійний, правцевий, поліомієлітний, коровий і паротитний антигени $[54,55]$.

Це власне була не ще одна наукова методика, а готовий тестовий набір 3 масовим виробництвом для використання в практичному секторі медицини. Наприкінці 1980-х, початку 1990-х рр. такі набори були доступні для усіх лабораторій стаціонарів і поліклінік (у той час багатопрофільні і спеціалізовані лікарні мали у своєму складі й власні поліклініки), принаймні, на території України. Ці набори активно використовувалися, оскільки були досить прості у виконанні й обліку, а також могли бути виконані навіть середнім медичним персоналом. Але з розвалом СРСР і з наступною економічною кризою, а також зі зміною спектру вакцин використання комплекту для РІЛ поступово припинилося. Практика використання цього набору показала, що його результати відносно оцінки небезпеки вакцинації не завжди були однозначні. Така думка існує серед фрахівців, у тому числі й клінічного імунологічного профрілю, і сьогодні. Проте, реальних даних про низьку діагностичну значущість РІЛ для оцінки ступеня специфрічної алергізації пацієнта до використовуваних вакцинних антигенів у доступних інформаційних джерелах немає. Але, відмовившись від РІЛ і тест-набору з антигенами 6 основних вакцин з національного календаря щеплень, ні наукова, ні практична вітчизняна, та й зарубіжна медицина за останні майже 30 років натомість не запропонували нічого! Таким чином, ось вже майже три десятиліття не проводиться реальна індивідуальна оцінка небезпеки вакцинації. У жодному сучасному офіційному керівництві з вакцинації, у тому числі й серед документів ВОО3, присвячених цій проблемі, ніяких даних про використання імуноалергічних методів дослідження 3 
вакцинними антигенами для прогностичної оцінки можливості розвитку індивідуальних імунопатологічних реакцій у відповідь на вакцинацію немає.

Такий стан вакцинації можна розцінювати як досить дивний, оскільки сьогодні імуноалергічні методи дослідження для прогнозу можливого розвитку алергічних реакцій (найчастіше на фрармакологічні препарати) 3 успіхом застосовуються в інших галузях медицини, наприклад, в таких як терапія, клінічна імунологія, алергологія, неврологія, невідкладна неврологія, хірургія i, навіть, стоматологія [56-59]. Крім «древньої» РІЛ у цих галузях сьогодні успішно використовуються такі ж «старі» методи діагностики імунопатології, як: «показник пошкодження лейкоцитів» (ППЛ); нефелометрія мікропреципітації сироватки за Уаньє; прямий тест дегрануляції базофілів та ін. [58]. Але в той же час сьогодні ці методи не використовуються для оцінки небезпеки вакцинації та її можливих ускладнень!

Складається ситуація, що при досить широкому спектрі способів і методів оцінки і прогнозу розвитку імунопатології у відповідь на сторонні антигени, якими, по суті, і є більшість із сучасних вакцин, імуноалергічні методи дослідження категорично не використовуються при проведенні імунопрофілактики, і, як було зазначено раніше, про них сьогодні навіть не згадують. Слід особливо наголосити, що сучасних (заснованих на нових технологіях) тестів оцінки небезпеки вакцинації взагалі немає! Нічого «нового» не запропоновано, але й від «старих» оцінкових тестів вже давно відмовилися.

У чому ж причина такої ситуації? Для відповіді потрібна ретроспектива 3 глибиною майже в 30 років 3 початковою точкою в часі - створення і впровадження в широку практику РІЛ $[54,55]$. На жаль, більшість фрахівців, які сьогодні безпосередньо займаються вакцинацією та оцінкою індивідуальної чутливості пацієнта до вакцин 3 календаря щеплень, негативно ставляться до способу оцінки небезпеки індивідуальної вакцинації за допомогою РІЛ (чи їі модифікацій). Вони пояснюють це низькою інформативністю прогнозу, приблизно на рівні не більше $50 \%$. Це означає, що, виходячи навіть зі шкільного курсу математики, така вірогідність (1/2) абсолютно очікувана при звичайних багаторазово повторюваних випадкових подіях, а отже реальна прогностична цінність необхідного прогнозу наближатиметься до нуля! Цікавий той факт, що ця інформація висловлюється тільки в усній формі, але офріційних даних про низьку прогностичну цінність РІЛ при вакцинації немає (принаймні, вона відсутня в доступних інфрормаційних джерелах).

Таким чином, це усього лише суто суб'єктивна оцінка або все ж є й об'єктивні причини, за якими довелося відмовитися від офіційно рекомендованого і використо- вуваного способу оцінки індивідуальної небезпеки вакцинації? Дійсно, якщо більшість проорільних фрахівців вказує на низьку інфрормативність вказаного способу оцінки, їх думку не можна ігнорувати, хоч цьому і немає офріційного підтвердження (точніше сьогодні воно недоступне), а отже ці дані все ж необхідно буде прийняти, хоч і просто емпіричні. 3 другого боку РІЛ з успіхом використовуються в інших галузях медицини.

Та повернімося усе ж майже на 30 років назад. 3 одного боку, ми маємо вже готовий, введений в широку клінічну практику, офріційний лабораторний набір, що містить шість антигенів основних вакцин 3 календаря щеплень. Але це було на початку 90-х років 20-го століття, коли стався розпад СРСР і на пострадянському просторі з'явилися нові незалежні держави зі своїм устроєм, своєю економікою, політикою та ін. Це украй важливо, оскільки в цих країнах почали поступово змінюватися системи охорони здоров'я, а, відповідно, й підходи до імунопрофрілактики інфекцій. Найголовніше, що змінилися використовувані раніше вакцини. Якщо раніше вони централізовано вироблялися у СРСР для усієї країни, то вже після розпаду СРСР в Україні почали використовуватися вакцини не лише російського виробництва, але й такі, що ввозяться з Європи, США та інших країн. Змінився навіть не спектр вакцин, а їх виробники. I якщо згаданий набір містив антигени вакцин, раніше продукованих у СРСР, і розроблявся для прогнозу небезпеки вакцинації при використанні саме цих вакцин, то при зміні спектру і складу вже нових вакцин прогностична цінність такого лабораторного тесту дійсно мала б істотно знизитися, що фактично й сталося і було підтверджено досвідом профільних фрахівців. Тому результат їх негативного досвіду був безпосередньо пов'язаний саме 3 цим, а отже і причина низької прогностичної цінності тест-набору для РІЛ полягала не в самому способі оцінки (самій реакції), а в зміні спектру вакцин, їх видозміні та вмісті. Таким чином, тест-набір для РІЛ зі «старими» вакцинними антигенами, не міг давати достовірну прогностичну оцінку для «нових» вакцин, що містять «нові», відмінні від «старих», вакцинні антигени. Непрямим підтвердженням цьому є досить висока діагностична цінність РІЛ в оцінці прогнозу й розвитку імунопатологічних реакцій та успішне ії̈ застосування в інших галузях медицини [5660].

Виходячи з наведеного, необхідно зробити логічний висновок, що РІЛ в оцінці індивідуального ризику розвитку імунопатології при вакцинації - невиправдано забута, а її можливості все ще не вичерпані. РІЛ сьогодні просто необхідно адаптувати до сучасних умов проведення вакцинації і власне до нових вакцин! Не варто придумувати щось кардинально нове для РІЛ. На пер- 
шому етапі необхідно адаптувати для вже розробленого набору РІЛ дози антигенів нових вакцин. Так, якщо в тест-наборі для РІЛ використовуються дози вакцинних антигенів еквівалентні 1 «робочій дозі», що міститься в об'ємі 0,01 мл, то логічно використовувати такі ж «робочі дози» для вакцинних антигенів вже «нових» вакцин. Правда, необхідно вказати, що сьогодні спектр вакцин навіть для однієї інфекції може бути досить великим (декілька вакцин для одної і тої ж інсрекції), а отже, для них будуть і різними «робочі дози». Постійним буде тільки об'єм (0,01 мл) в якому знаходитиметься 1 «робоча доза» вакцинного антигену. Хід РІЛ, її забезпечення й облік повинні залишатися колишніми і не відрізнятися від «оригінальної» методики, розрахунок результатів якої полягає в тому, яке відносне число (наприклад, відсоток) лейкоцитів, що зруйнувалися під впливом вакцинного антигену, виявлене у конкретного пацієнта.

Розрахунок простий і здійснюється за фрормулою: ПІВ = (K-O)/К, де «ПІВ» - показник імунолейкоцитолізу; «К»- число лейкоцитів у контролі (без вакцинного антигену); «О» - число лейкоцитів у досліді (інкубація 3 вакцинним антигеном).

Облік РІЛ також не складний. Так, якщо рівень лізованих під дією антигену клітин буде менше 0,2 (<20\%) - сенсибілізації пацієнта до конкретного вакцинного антигену немає і вакцинація цією вакциною може бути рекомендована, за відсутності клінічних і/або інших протипоказань. Якщо ж показник буде в інтервалі 0,2-0,3 (20-30 \%), то має місце помірна сенсибілізація до цього вакцинного антигену і вакцинація має бути відкладена і можлива (проведена через якийсь час після курсу десенсибілізуючої та адаптивної терапії) тільки за умови повторного дослідження у разі відсутності сенсибілізації. Якщо показник РІЛ більше 0,3 (>30 \%) - має місце виражена сенсибілізація до вакцинного антигену і щеплення протипоказане на термін не менше 6 міс. і можливе тільки за відсутності сенсибілізації до цього антигену і також при повторному дослідженні в РІЛ.

Залишається невирішеним тільки одне питання якою має бути «робоча доза» конкретної вакцини і які критерії фрормування й кількісні характеристики такої «дози». Відомо, що основний діючий інгредієнт вакцини - це специфічний антиген (крім ДНК-вакцин), де його 1 доза (вказується в якому об'ємі) виражається в дуже різному вигляді: мкг; МО (міжнародних одиницях); МОО (міжнародних оптичних одиницях); фрлокулюючих одиницях; числа ТЦД50 (тканинних цитопатичних доз для 50 \% клітин у тканинній культурі для живих вакцин); числа вірусних часток (для інактивованих вакцин) та ін. Стає очевидним, що якось уніфікувати ці показники і привести їх до якої-небудь єдиної розмірності або одиниці практично неможливо. Тому дійсно доведеться провести умовну стандартизацію та уніфікацію цих показників для РІЛ, які дійсно і сьогодні виражатимуться в «робочих дозах» для кожної з вакцин. Поки іншого шляху немає. Слід вказати, що для живих вакцин їх інактивація для проведення РІЛ істотно спотворить результати, оскільки при інактивації (термічної або хімічної), як правило, відбуваються значні зміни в первинних вакцинних антигенах. Можливо, саме інактивація живих вакцин (корова, паротитна і поліомієлітна) у тестнаборі для РІЛ спочатку істотно змінювала ії результати і призводила до їх неправильної інтерпретації, а, можливо, навіть і дискредитації методу РІЛ.

Отже, у нас $€$ початковий матеріал - вакцина та її дозування у вигляді «дози», що вводиться, і неважливо в яких одиницях вона виражена. Для РІЛ потрібна та ж вакцина, але вже в «робочій дозі». Логічно, що «робоча доза» буде похідною від «введеної першої дози» і буде істотно меншою від неї. Але «робоча доза» формуватиметься 3 тієї ж вакцини і з її «першої дози». Основне питання як це зробити і як співвіднести «першу дозу» для вакцинації 3 «робочою дозою» для постановки РІЛ? Зробити це досить просто, використовуючи вже розроблений методичний підхід для визначення дози «алергодіагностикуму» для РІЛ [57, 58, 60-63]. Так, необхідною «робочою дозою» вакцинного антигену для РІЛ буде те мінімальне розведення «першої вакцинної дози» (робоче розведення початкової вакцини), яке не викликатиме в РІЛ неспецифічного пошкодження лейкоцитів у клінічно здорових осіб вище допустимих для таких реакцій $10 \%$. Таким чином, ми можемо максимально наблизити РІЛ до різного роду і виду антигенних вакцин. Але у цьому контексті необхідно зазначити, що для унісрікації методу і максимального його наближення до конкретної вакцини все ж було б необхідним зобов'язати виробників вакцин виконувати ці дослідження самостійно і в інструкціях до вакцин вказувати таку «робочу дозу» i/або готувати і поставляти до кожної з партії вакцин такі «робочі дози» (окремо або в одному флаконі «робочих доз» $з$ вказівкою її об'єму) цієї ж вакцини для РІЛ. Зазначимо, що цей методичний підхід для визначення «робочої дози» алергодіагностикуму використовується і для інших реакцій, що дозволяють виявляти специсічну сенсибілізацію у пацієнтів. Це такі реакції: визначення показника пошкодження нейтрофрілів (ППН); альтерація лейкоцитів; агломерація лейкоцитів. Але у вказаних джерелах все ж перевага віддається РІЛ, як простішій, показовішій, більш інфрормативній і достовірній.

У цьому зв'язку слід відразу вказати, що для ДНКвакцин пряме застосування РІЛ неможливе, оскільки використання цього класу вакцин припускає вироблення антигену власне у вакцинованому організмі з фрорму- 
ванням у нього згодом імунітету на вироблений вже в його організмі антиген, запрограмований у введеній ДНК. Але і в даному випадку можливе проведення у пацієнта опосередкованої РІЛ з антигеном, отриманим при реалізації програми ДНК, що вводиться, наприклад в іншому живому організмі. При цьому оцінка прогностичної небезпеки використання ДНК-вакцин значно складніша і лежить навіть в іншій площині з використанням інших методичних підходів, відповідних механізму дії таких вакцин. Але ця проблема перебуває у ще досить віддаленій перспективі, а основними і широко використовуваними на практиці на сьогодні залишаються все ж звичайні вакцини, що містять специфрічні антигени (живі та інактивовані вакцини, а також анатоксини), що забезпечують у вакцинованої особи активну імунну відповідь з формуванням активного клітинного і гуморального імунітету з формуванням захисного рівня специорічних антитіл, як правило, класу IgG і пулу клітин пам'яті.

Слід сказати, що РІЛ на сьогодні хоч і є найбільш використовуваною та оптимальною для практичного застосування реакцією, але вона - не єдиний спосіб і метод оцінки і прогнозу можливого розвитку імунопатологічних реакцій у відповідь на введені антигени. Це, крім РІЛ: реакція альтерації лейкоцитів; ППН; реакція агломерації лейкоцитів; прямий тест дегрануляції базофрілів; несрелометрія мікропреципітації сироватки за Уаньє та ін. [58]. Але все-таки слід вказати, що їх попередниками, майже 50-70 років тому, були реакція специфрічного лейколізу (у сучасному варіанті - РІЛ), розроблена і запропонована в 1946-1947 pp. С.В. Favour, яка вже в 1961 р. широко використовувалася в модифікації Н. Pettit, а також запропонований В.А. Фрадкіним у 1962 р. тест пошкодження нейтрофрілів, які використовувалися для виявлення алергічних реакцій переважно негайного і сповільненого типу [61-64]. Згадані «сучасні» способи діагностики використовуються і сьогодні, але вони мають різну інформативність, діагностичну значущість і найголовніше - складніші та трудоємніші у виконанні, порівняно з РІЛ в її сучасній постановці.

Дійсно, вже минуло більше пів-століття, але нічого кардинально нового все ще не запропоновано! Виходячи 3 наведеного, нині необхідно офріційно дати «друге життя» РІЛ в оцінці прогнозу небезпеки вакцинації та її побічних ефектів, пов'язаних з можливим розвитком імунопатологічних реакцій (алергічних реакцій негайного і сповільненого типу), оскільки офріційних альтернативних методів для таких досліджень на сьогодні фрактично немає. Та існують і сучасні розробки для оцінки й прогнозу небезпеки вакцинації, що використовують іншу методологію [61]. Але усе ж їх «новизна» дуже сумнівна, оскільки по суті це банальна шкірно-алергічна проба, щоправда, із вакцинними антигенами.
Таким чином, найбільш оптимальним варіантом для відродження методів і способів оцінки і прогнозу небезпеки і побічних ефректів від вакцинації, пов'язаних 3 розвитком імунопатологічних реакцій, залишається РІЛ. Тому сьогодні необхідно створити науково-практичну програму за оцінкою діагностичної значущості РІЛ стосовно вакцинації та сучасних вакцин, а також розробки і створення нових засобів, способів і методів прогнозу небезпеки і побічних ефектів вакцинації. Тільки така програма та її реальна результативність зможе вирішити глибокий конфлікт інтересів відносно вакцинації між індивідуумом і популяцією, зламати усталений сьогодні в нашому суспільстві стереотип негативного ставлення до активної імунопрофрілактики, низької якості вакцин і їх високої потенційної небезпеки. Реалізація цієї програми дозволить відійти від «поголовності» та максимально індивідуалізувати вакцинацію і ревакцинацію для кожної людини, дозволить їй усвідомлено разом 3 клініцистом ухвалювати зважене поетапне рішення про необхідність, доцільність і можливість вакцинації, реально оцінивши усі її можливі індивідуальні ризики і небезпеку. Тільки в цьому випадку реанімуватиметься прихильність і довіра населення до імунопрофрілактики, а у держави зникне необхідність у заходах до їі примусу. Але слід наголосити, що для відновлення довіри людей до вакцинації держава вже сьогодні повинна цілеспрямовано направити свої контролюючі та репресивні функції не на примус населення до вакцинації, а реалізовувати навіть «агресивний» контроль за якістю вакцин і проведенням імунопрофрілактики.

Закінчуючи дослідження, необхідно звернути увагу на те, що запропоновані методи та способи прогнозування серйозних і тяжких «поствакцинних ускладнень», на жаль, здатні прогнозувати тільки ті з них, які патогенетично безпосередньо пов'язані саме з розвитком алергічних (найчастіше анафрілактичних) реакцій на введення вакцин. Дійсно, такі поствакцинні ускладнення, як анасрілактичні реакції та анафрілактичний шок, тяжкі генералізовані алергічні реакції (негайного і сповільненого типів) у вигляді ангіоневротичного набряку, синдромів Лайєла, Стівенса-Джонсона, сироваткової хвороби, алергічних та автоімунних енцефаломієлітів і поліневритів складають більшість поствакцинних ускладнень (незалежно від їх тяжкості), але все-таки не є єдиними 3 них. Залишається ще достатнє число тяжких поствакцинних ускладнень, безпосередньо не пов'язаних 3 алергічними реакціями, а зумовлених застосуванням «живих» (і деяких «неживих» ДНК-вакцин). Сама суть і патогенетичний механізм дії «живих» вакцин і створення ними специфічного імунітету спрямовані на закономірний розвиток у вакцинованої особи «малих», тобто таких, що вважаються «безпечними», клінічних фрорм і 
варіантів перебігу інфекцій, спричинених вакцинними штамами мікроорганізмів. Але в окремих, навіть клінічно здорових, людей такі «малі» і «безпечні» фрорми вакцинних інсрекцій можуть трансорормуватися у тяжкі генералізовані форми, внутрішньоутробні аномалії та вади розвитку плода, енцесраліт, менінгоенцефаліти, енцефраломієліти, неврити, поліневрити, артрити. Такі ускладнення можна прогнозувати тільки у разі наявності у людини імунодефріцитних станів, до яких належать не лише ВІЛ-інсрекція, онкопатологія, застосування імунодепресантів, а і звичайна вагітність. Це загальновідомо і в даних випадках, дійсно, «живі» вакцини використовувати фрактично заборонено. Але у клінічно здорових осіб можуть мати місце не розпізнані імунодефріцитні стани, у тому числі генетично зумовлені й чітко спрямовані відносно окремих інорекцій. Тому саме у таких людей має місце найвищий ризик розвитку тяжких вакцинних інфекцій. Такі «вакцинні» інфекції з тяжким перебігом можуть спостерігатися не лише у щеплених осіб, а й у людей, які тісно з ними контактують і не мають специфічного імунного захисту. Добре відомі випадки вакцин-асоційованого поліомієліту в дорослих і дітей, яким не проводилася вакцинація, але вони перебували в тісному контакті з особами (найчастіше дітьми), яким проводилася імунопрофрілактика живою оральною поліомієлітною вакциною. Такі ускладнення навіть сьогодні прогнозувати не реально і їх дійсно можна віднести до розряду поки що «непрогнозованих». Але сьогодні вже вирішується і ця проблема шляхом поступового переходу від «живих» до вакцин інших типів, хоча необхідно згадати, що ефективність «живих» вакцин була і залишається однією 3 найвищих серед інших засобів імунопрофрілактики щодо створення специфрічного протективного імунітету.

Практично усі наші, у тому числі й імунопатологічні, реакції, чутливість до різних патогенів, особливості індивідуального патогенезу та перебігу різних захворювань генетично обумовлені. Наш генетичний нуклеотидний код усіх 25-30 тис. генів вже відомий з 2003 р. і сьогодні секвенування повного індивідуального геному не лише можливе протягом декількох діб, але й фрінансово доступне. Тому залишилося небагато - усього лише знайти взаємозв'язок наших генів з особливостями відповіді на вакцини. Особливе значення це має для нового класу ДНК-вакцин, оскільки вже доведеться враховувати взаємодію геному людини і геномів вакцин. При сучасному розвитку цифрових технологій, потужних і швидкодіючих комп'ютерів, здатних у короткі терміни обробляти величезні масиви інформації, зіставляти дані й знаходити їх тісний взаємозв'язок, - вирішення проблеми прогнозування поствакцинних ускладнень - справа найближчого майбутнього. Головне - мати непереборне бажання і потребу розв'язати цю проблему, а способи і засоби її вирішення у нас вже $є$.

Підбиваючи підсумок, необхідно ще раз підкреслити виняткову необхідність реалізації індивідуальної програми вакцинації/ревакцинації для кожної людини, що припускає описаний вище алгоритм: спочатку - оцінка необхідності конкретної вакцинації за рівнем захисних антитіл (з урахуванням рекомендацій ВООЗ); на другому етапі - оцінка доцільності вакцинації; на третьому етапі, за необхідності і/або доцільності вакцинації усебічна оцінка можливості проведення специфрічної імунопрофрілактики з урахуванням клінічних протипоказань, а також індивідуальних ризиків, побічних ефректів і небезпеки розвитку алергічних реакцій негайного типу при використанні у конкретного пацієнта конкретної вакцини. Так, це не дасть 100 \% гарантії безпеки, але безумовно зведе небезпеку імунопрофілактики до досяжного на сьогодні можливого мінімуму і, найголовніше, - дасть можливість пацієнтові усвідомлено разом з клініцистом ухвалювати рішення про застосування конкретної вакцини, а в разі розвитку можливих, але не прогнозованих ускладнень вакцинації зніме з клініциста юридичну відповідальність, оскільки ним спільно з пацієнтом були застосовані усі можливі засоби, методи і способи для їх уникнення. Крім цього, одною з обов'язкових умов має бути створення відповідних нормативних документів, в яких будуть дані детальні рекомендації, а не бездумний «протокол», відображений алгоритм індивідуальної імунопрофілактики з використанням сучасних методів достовірного прогнозування ризиків і небезпеки вакцинації. 


\section{Література}

1. Медуницын Н.В. Вакцинология / Н.В. Медуницын. - Изд. 2-е, перераб. и доп. - М.: Триада-Х. - 2004. - 448 с.

2. Крюи П.Д. Охотники за микробами / П.Д. Крюи. - М.: АСТ, 2017. -480 с.

3. Шевелев А.С. Последний подвиг Луи Пастера / А.С. Шевелев, Р.Ф. Николаева. - М.: Медицина. - 1988. - 112 с.

4. Возианова Ж.И. Инфекционные и паразитарные болезни: учеб. пособие в 3 томах. Т. 1 / Ж.И. Возианова. - К.: Здоров'я, 2001. -903 c.

5. Зуева Л.П. Эпидемиология: учебник / Л.П. Зуева, Р.Х. Яфаев. - СПб: ООО изд. «Фолиант», 2005. - 752 с.

6. Поствакцинальные осложнения (клиника, диагностика, лечение, профилактика): Пособие для практического врача / Е.А. Лакоткина, С.М. Харит, Т.В. Черняева, Н.К. Брусов. - Под ред. чл.-корр. РАМН д.м.н., профр. В.В. Ивановой. - СПб: Санкт-Петербургский медицинский информационно-аналитический центр, 2004. - 79 с.

7. Медуницын Н.В., Покровский В.И. Основы иммунопрофилактики и иммунотерапии инфекционных болезней: Учеб. пособие. - М.: ГЭОТАР-Медиа, 2005. - 512 с.

8. Специалисты о прививках. Национальный календарь прививок // http://www.yaprivit.ru/for-parents/\#commentcontainer

9. Systema Naturae 2000 // http://sn2000.taxonomy.nl

10. Возианова Ж.И. Инфекционные и паразитарные болезни: учеб. пособие в 3 томах. Т.З / Ж.И. Возианова. - Київ: Здоров'я 2002. - С. 758-790

11. Научный обзор исследований вируса натуральной оспы, 1999-2010 гг. // ВО3, декабрь 2010. - 132 c. // https://apps.who.int/ iris/bitstream/handle/10665/70508/ WHO_HSE_GAR_BDP_2010.3_ rus.pdf?sequence $=4$

12. Чумаченко Т.О. Імуноепідеміологічний моніторинг населення в системі епідеміологічного нагляду за інфекціями, контрольованими засобами імунопрофрілактики: Автореф. дисс. ... докт. мед. наук. - Київ, 2009. - 36 с.

13. Патент деклараційний на винахід № UA 51426 А Україна МПК А61B 10/00 Спосіб діагностики несприйнятливості до інфекцій / Т.О. Чумаченко, М.М. Колесников, О.М. Карабан. - Харківський державний медичний університет - № 2002032184; Заявл. 19.03.2002; Надрук. 15.11.2002. - Бюл. - № 11. - 2 с.

14. Патент на корисну модель № UA 20819 U Україна. МПК G01N 33/51 Спосіб оцінки стану післящеплювального протикорового імунітету / Т.О. Чумаченко, Г.В. Сіріца, Т.О. Чумаченко, Г.В. Сіріца. - № u200608862; Заявл. 08.08.2006; Надрук. 15.02.2007. - Бюл. - № 2. -2 с.

15. Напруженість популяційного імунітету до дифтерії та правця у Дніпропетровській області / Г.О. Ревенко, В.В. Маврутенков, О.П. Штепа та ін. / Збір. наук. праць Української військово-медичної академії «Проблеми військової охорони здоров'я». - Київ, 2016. - Вип. № 45, Т. 2 - С. 202-207.

16. Уровень напряженности иммунитета к дифтерии и столбняку у населения республики Крым / И.З. Каримов, М.В. Горовенко, Н.А. Пеньковская и др. // Инфекция и иммунитет. - 2015. - Т. 5, № 2. - С. 165-170.

17. Інорормаційні технології в системі моніторингу за популяційним імунітетом проти дифтерії та правця: Метод. реком. Львівський НДІ епідеміології та гігієни.

18. Імунодіагностика дифтерійної інфекції / Ю.Л. Волянський, Ж.М. Маніна, Л.І. Слюсар та ін. // Інформ. лист МОЗ України, Укрмедпатентінформ, «Вірусологія та мікробіологія». - 1996. - Вип. № $1 .-3$ c.

19. Наказ МОЗ України № 359 від 19.12.1997 р. (чинний) «Номенклатура лікарських спеціальностей» // https://zakon.rada.gov. ua/laws/show/z0015-98
20. Наказ МОЗ України № 427 від 11.05.2016 р. (чинний) «Про внесення змін до наказу Міністерства охорони здоров'я України від 23.02.2000 № 33 «Про штатні нормативи та типові штати закладів охорони здоров'я» // https://zakon.rada.gov.ua/rada/show/ v0427282-16

21. Закон України від 24.02.1994 р. (чинний) «Про забезпечення санітарного та епідемічного благополуччя населення» // https:// zakon.rada.gov.ua/laws/show/4004-12

22. Закон України від 06.04.2000 р. (чинний) «Про захист населення від інфекційних хвороб» // https://zakon.rada.gov.ua/laws/ show/1645-14

23. Наказ МОЗ України № 595 від 16.09.2011 р. (чинний) «Про порядок проведення профрілактичних щеплень в Україні та контроль якості й обігу медичних імунобіологічних препаратів» // https:// zakon.rada.gov.ua/laws/show/z1159-11

24. Наказ МОЗ України № 551 від 11.08.2014 р. (чинний) «Про удосконалення проведення профрілактичних щеплень в Україні» // https://zakon.rada.gov.ua/laws/show/z1237-14

25. Наказ МОЗ України № 947 від 18.05.2018 р. (чинний) «Про внесення змін до Календаря профілактичних щеплень в Україні» // http://moz.gov.ua/article/ministry-mandates/nakaz-moz-ukraini-vid18052018--947-pro-vnesennja-zmin-do-kalendarja-profilaktichnihscheplen-v-ukraini

26. Імунопрофрілактика в практиці сімейного лікаря: навч. посіб / А.П. Подавленко, Т.О. Чумаченко, В.І. Задорожна, І.С. Кратенко. - Х.: Фоліо, 2008. - 222 с.

27. Харит С.М.,. Черняева Т.В, Лакоткина Е.А. Структура заболеваний поствакцинального периода (анализ наблюдений за 40 лет) // Эпидемиология и вакцинопрофилактика. - 2010. - Т. 2, № 51. - С. 64-69.

28. Вопросы и ответы об иммунизации и безопасности вакцин. Онлайновые вопросы и ответы. Март 2018 г. // https://www.who.int/ features/qa/84/ru/

29. Вакцинація у запитаннях та відповідях: Метод. реком. I Національна асоціація адвокатів України, Комітет медичного і фармацевтичного права та біоетики. - 2018. - 24 с. // http://unba. org.ua/assets/uploads/77b7b540396ed691df9b_file.pdf

30. Інструкція для медичного застосування лікарського засобу (медичного імунобіологічного препарату) ІНФАНРИКС ГЕКСА ${ }^{\mathrm{TM}}$ (INFANRIX HEXA'M) - комбінована вакцина для профілактики дифтерії, правця, кашлюку (ацелюлярний компонент), гепатиту $\mathrm{B}$, поліомієліту та захворювань, збудником яких є Haemophilus influenzae типу b // http://www.drlz.com.ua/ibp/lz_www.nsf/id/ BEBA 8BD9E811B69BC225838B0032F0B2/ \$file/UA162350101_49A0.mht

31. Ерш А.В. Разработка диагностического набора для выявления антител к возбудителям кори, краснухи и эпидемического паротита методом мультиплексного дот-анализа: Дисс. ... докт. биол. наук. - Кольцово, 2015. - 154 с.

32. Evaluation of eight anti-rubella virus immunoglobulin G immunoassays that report results in international units per milliliter / [W. Dimech, L. Panagiotopoulos, B. Francis et al.] // Journal of Clinical Microbiology. - 2008. - Vol. 46. - P. 1955-1960.

33. Tisher A. Standardization of measles, mumps and rubella assays to enable comparisons of seroprevalence data across 21 st European countries and Australia / A. Tisher, N. Andrews, G. Kafatos // Epidemiol. Infect. - 2007. - Vol. 135. - P. 787-797.

34. Наказ МОЗ України від 04.07.2006 р. (чинний) № 441 «Про затвердження методичних вказівок «Організація і проведення імунологічного моніторингу за інфекціями, які контролюються засобами специфрічної профілактики (дифтерія, правець, кашлюк та кір)» // http://old.moz.gov.ua/ua/portal/dn_20060704_441.html 
35. Медуницын Н.В. Вакцины. Новые способы повышения эффективности и безопасности вакцинации / Н.В. Медуницын, А.Н. Миронов // Вопросы вирусологии. - 2012; приложение 1. C. $43-51$.

36. Персональный и коллективный иммунитет / Н.В. Медуницын, Ю.В. Олефир, В.А. Меркулов, В.П. Бондарев // Биопрепараты. Профрилактика, диагностика, лечение. -2016. - Т. 16, № 4. - С. 195-207.

37. Бектимиров Т.А. Рекомендации ВОЗ по профрилактике гемофильной инфекции тип В / Т.А. Бектимиров // Вакцинация. 2003. - № 2. - C. 4-5.

38. Крамарь Л.В. Гемофиильная инфекция у детей: проблемы и перспективы / Л.В. Крамарь, Ю.О. Хлынина // Лекарственный вестник. - 2011. - Т.6, № 3. - С. 42-47.

39. Поствакцинальний імунітет проти кору та епідемічного паротиту у ВІЛ-інфікованих дітей / А.П. Волоха, Л.І. Чернишова, І.В. Раус, І.В. Демчишина // Современная педиатрия. - 2014. - Т. 8 , № 64. - C. 126-131.

40. ENGERIX-B [Hepatitis B Vaccine (Recombinant)] injectable suspension, for intramuscular use Initial U.S. Approval: 1989. - 16 p. // https://www.fda.gov/downloads/biologicsbloodvaccines/vaccines/ approvedproducts/ucm224503.pdf

41. Наказ МОЗ України № 196 від 14.07.98 р. «Про посилення заходів щодо попередження захворювань на поліомієліт в Україні» // https://zakon.rada.gov.ua/rada/show/v0196282-98

42. Уровень IgG-антител к вирусу кори в пуповинной крови новорожденных с учетом возраста матерей / [М.П. Костинов, А.Д. Шмитько, И.И. Бочарова и др.] // Эпидемиология и инфекционные болезни. - 2014. - № 3. - С. 30-34

43. Полиомиелитные вакцины и иммунизация против полиомиелита в предликвидационный период: документ по позиции BO3. - 20 c. // https://www.who.int/immunization/documents/Polio_ PP_June_2010_RU.pdf

44. Организация и проведение серологического мониторинга состояния коллективного иммунитета к инфекциям, управляемым средствами специфической профилактики (дифтерия, столбняк, коклюш, корь, краснуха, эпидемический паротит, полиомиелит, гепатит В): Методические указания. - М.: Федеральный центр гигиены и эпидемиологии Роспотребнадзора, 2011. - 19 с.

45. Юминова Н.В. Диагностика краснухи в Российской Федерации / Н.В. Юминова // Бюллетень вакцинации. - 2009. - № 6 (36). - C. 5-6.

46. Serum levels of rubellaspecific antibodies in Swedish women following three decades of vaccination programmes / M. Kakoulidou, M. Forsgren, I. Lewensohn-Fuchs, K. Johansen // Vaccine. - 2010. Vol. 28. - N 4. - P. 1002-1007.

47. Kinetics of antibody and memory $B$ cell responses after MMR immunization in children and young adults / [M. Kakoulidou, H. Ingelman-Sundberg, E. Johansson et al.] // Vaccine. - 2013. Vol. 31. - № 4. - P. 711-717.

48. Rubella seroprevalence in the first birth cohort reaching fertility age after 20 years of two dose universal vaccination policy in Israel / [H. Levine, O. Ankol, V. Rozhavski et al.] // Vaccine. - 2012. - Vol. 30. - N 50. - P. 7260-7264.

49. Prevalence of IgG Antibody Against Measles, Mumps and Rubella in Bangladeshi Children: A Pilot Study to Evaluate the Need for Integrated Vaccination Strategy / R. Sultana, M.M. Rahman, Z. Hassan, M.S. Hassan // Scand. J. Immunol. - 2006. - Vol. 64. - P. 684-689.
50. Measles Virus-Specific Antibody Levels in Individuals in Argentina WHO Received a One-Dose Vaccine / [M.H. Arguelles, M.L. Orellana, A.A. Castello et al.] // J. Clin. Microbiol. -2006. - Vol. 44. - N 8. - P. 2733-2738.

51. Наказ МОЗ України № 198 від 05.08.1999 р. «Про вдосконалення профілактики, діагностики та лікування правця» // МО3 України. - Київ: «Поліграфріст», 1999. - 19 с.

52. Вакцина против дифтерии. Еженедельный эпидемиологический бюллетень ВОЗ 20 января 2006.- 2006.- № 3. - 9 c. // https://www.who.int/immunization/Diptheria_Russian_11Apr08. pdf

53. Еженедельный эпидемиологический бюллетень ВО3, 23 февраля 2018 года, 93-й год. - 2018. - № 8, 93,73-96 // http://www. who.int/wer

54. Наставление по применению комплекта ингредиентов для постановки реакции иммунолейкоцитолиза (РИЛ) с вакцинальными антигенами / Выписка из «Метод. рекоменд. по профилактической иммунизации детей с измененной реактивностью» // Научно-производственная лаборатория «Иммунодиагност» Донецкой обл. СЭС и Донецкого мед. института. МЗ СССР, М., 1989. - 2 с.

55. Методические рекомендации по профрилактической иммунизации детей с измененной реактивностью. МЗ СССР, утверждено 25.10.1989 г.

56. L-лизина эсцинат в комплексе интенсивной терапии полиэтиологического поражения головного мозга / [В.И. Черний, А.Н. Колесников, Е.В. Черний и др.] // Международный неврологический журнал. - 2006. - Т. 3, № 7. - С. 91-97.

57. Патент № RU 2211452 C2 Россия. MПК G 01 N 33/50, 33/48 Способ выявления in vitro эффекта аллергизации на введение каптоприла / [Ю.М. Лопатин, О.В. Илюхин, А.Т. Яковлев и др.] // Волгоградская медицинская академия. - № 2000104205/14; Заявл. 18.02.2000; Опубл. 27.08.2003

58. Клінічна імунологія та алергологія: Навч. посібн. / [О.М. Біловол, П.Г. Кравчун, В.Д. Бабаджан та ін.]. - Х.: «Грифр», 2011. - 550 с.

59. Наказ УОЗ від 04.02.2014 №74-ОД «Про скерованість дітей, які мають медикаментозну алергію для проведення реакції імунолейкоцитолізу при хірургічному стоматологічному втручанні» // http://udental.sumy.ua/\%D0\%BD\%D0\%BE\%D0\%B2\%D0\%B8\%D0 \%BD\%D0\%B8/page/3/

60. Новиков Д.К. Клеточные методы иммунодиагностики / Д.К. Новиков, В.И. Новикова. - Минск: Беларусь, 1979. - 222 с.

61. Шепелев А.А. Использование иммуноаллергических реакций лейкоцитов крови при бактериальной дизентерии. Метод. реком. МЗ РСФСР, Астраханский госуд. медицинский інститут, Астрахань, 1980. - 8 с.

62. Favour C.B. Lytic effect of bacterial products on lymphocytes of tuberculosis animals / C.B. Favour // Proc. Soc. Exp. Biol. Med., 1947. - Vol. 65, N 2. - P. 269-272.

63. Pettit $\mathrm{H}$. In vitro leukocytolysis in presence of pollen and house dust antigens / H. Pettit, H.E. Sullivan, E.D. Hhart // J. Allergy. - 1961. - N 32. - P. 30-35.

64. Патент № RU 2175245 C2 Россия. МПК А61K 39/00 , 39/165, A61P 31/00 Способ вакцинации против кори детей с аллергическими заболеваниями / С.М. Харит, Е.А. Марцишевская // НИИ детских инфекций. - № 2000102067/14; Заявл. 26.01.2000; Опубл. 27.10.2001. 


\section{References}

1. Medunitsin, N.V. (2004). Vaktsinologiya [Vaccinology]. Moscow: Triada-X [in Russian].

2. Kriui, P.D. (2017). Okhotniki za mikrobami [Microbe hunters]. Moscow: ACT [in Russian].

3. Shevelev, A.S. (1988). Posledniy podvig Lui Pastera [Louis Pasteur's last feat]. Moscow: Meditsina [in Russian].

4. Vozyanova, Zh.I. (2001). Infektsionnye i parazitarnye bolezni [Infectious and parasitic diseases]. Kyiv: Zdorovia [in Russian].

5. Zuyeva, L.P. (2005). Epidemiologiya [Epidemiology]. Saint Petersburg: Foliant [in Russian].

6. Lakotkina, E.A., Kharit, S.M., Chernyayeva, T.V. \& Brusov, N.K. (2004). Postvaktsinalnyye oslozhneniya (klinika, diagnostika, lecheniye, profilaktika): Posobiye dlya prakticheskogo vracha [Post-vaccination complications (clinical presentation, diagnostics, treatment, prevention): A guidelines for the practical doctor]. Saint-Petersburg: Saint-Petersburg Medical Information and Analytical Center [in Russian].

7. Medunitsin, N.V. \& Pokrovskii, V.I. (2005). Osnovy immunoprofilaktiki i immunoterapii infektsionnykh bolezney: Uchebnoye posobiye [Basics of immune prophylaxis and immunotherapy for infectious diseases: Educational manual]. Moscow: Geotar-Meditsina [in Russian].

8. (2019). Spetsialisty o privivkakh. Natsionalnyy kalendar privivok [Specialists about vaccination. National vaccination calendar]. Retrieved from http://www.yaprivit.ru/for-parents/\#commentcontainer [in Ukraine].

9. Systema Naturae 2000. (2019). Retrieved from: http://sn2000. taxonomy.nl

10. Vozyanova, Zh.I. (2002). Infektsionnye i parazitanye bolezni [Infectious and parasitic diseases]. Kyiv: Zdorovia [in Russian].

11. (2010). Nauchnyy obzor issledovaniy virusa naturalnoy ospy, 1999-2010 gg. [Scientific review of variola virus research, 1999-2010]. WHO, December 2010. Retrieved from: https://apps.who.int/iris / bitstream/handle/10665/70508/WHO_HSE_GAR_BDP_2010.3_rus. pdf?sequence $=4$ [in Russian].

12. Chumachenko, T.O. (2009). Imunoepidemiologichnyi monitoring naselennia $v$ systemi epidemiolohichnoho nahliadu za infektsiiamy, kontroliovanymy zasobamy imunoprofilaktyky [Immune and epidemiological monitoring of the population in the system of epidemiological surveillance of infections by controlled methods of immune prophylaxis]. Doctor's Extended abstract. Kyiv [in Ukrainian].

13. Chumachenko, T.O., Kolesnykov, M.M. \& Karaban, O.M (2002). Patent UA 51426 A. Ukraina, MPK A61B 10/00. Sposib diahnostyky nespryiniatlyvosti do infektsii. [The method of diagnostics insusceptibility to infections]. N 2002032184; Byul.N 11 [in Ukrainian].

14. Chumachenko, T.O. \& Siritsa, G.V. (2007). Patent UA 20819 U Ukraina, MPK G01N 33/51. Sposib otsinky pisliashchepliuvalnoho protykorovoho imunitetu [The method for assessing the state of vaccine immunity against measles]. N u20060886; Byul.N 2 [in Ukrainian].

15. Revenko, H.O., Mavrutenkov, V.V., Shtepa, O.P. Rezvykh, V.H., Hamota, I.O., Revniaha, S.V. (2016). Napruzhenist populiatsiinoho imunitetu do dyfterii ta pravtsia u Dnipropertrovskii oblasti [Intensity of population immunity to diphtheria and tetanus in Dnipropetrovsks region]. Problemy viiskovoi okhorony zdorovia - Problems of Military Health Care: Collection of scientific works of the Ukrainian Military Medical Academy, 2 (45), (pp. 202-207). Kyiv [in Ukrainian].

16. Karimov, I.Z., Gorovenko, M.V., Penkovskaya, N.A., Midikari, A.S., Shmoylov, D.K., Kozlovskiy O.A. (2015). Uroven napryazhonnosti immuniteta $\mathrm{k}$ difterii i stolbnyaku u naseleniya respubliki Krym [The level of intensity of immunity to diphtheria and tetanus in the population of the Republic of Crimea]. Infektsiya i immunitet - Infection and Immunity, 5 (2), 165-170 [in Russian].
17. Informatsiini tekhnolohii v systemi monitirynhu za populiatsiinym imunitetom proty dyfterii ta pravtsia [Information technologies in the monitoring system for population immunity against diphtheria and tetanus. Methodical recommendations]. Lviv Research Institute of Epidemiology and Hygiene [in Ukrainian].

18. Volianskyi, U.L., Manina, Zh.M., Sliusar, L.I. Verezub, L.G., Babich, Ye.M., Selishcheva, L.M. et al. (1996). Imunodiagnostyka dyfteriinoi infektsii [Immunodiagnostics of diphtheria infection - Information letter of the Ministry of Health of Ukraine, Ukrmedpatentinform, «Virology and Microbiology»]. Kyiv [in Ukrainian].

19. Nakaz MOZ Ukrainy № 359 (chynnyi) «Nomenklatura likarskykh spetsialnostei» [Order of the Ministry of Health of Ukraine No. 359 «Nomenclature of medical specialties»]. (19.12.1997). Kyiv. Retrieved from: https://zakon.rada.gov.ua/laws/show/z0015-98 [in Ukrainian].

20. Nakaz MOZ Ukrainy № 427 (chynnyi) «Pro vnesennia zmin do nakazu MOZ Ukrainy vid 23.02.2000 № 33 «Pro shtatni normatyvy ta typovi shtaty zakladiv okhorony zdorovia Ukrainy» [Order of the Ministry of Health of Ukraine № 427 «On Amendments to the Order of the Ministry of Health of Ukraine dated February 23, 2000 No. 33 «On staffing standards and standard of health care settings»]. (11.05.2016). Kyiv. Retrieved from: https://zakon.rada.gov.ua/rada/show/v042728216 [in Ukrainian].

21. Zakon Ukrainy «Pro zabezpechennia sanitarnoho ta epidemiolohichnoho blahopoluchchia naselennia» [Law of Ukraine "On ensuring the sanitary and epidemic well-being of the population»]. 24.02.1994. Kyiv. Retrieved from: https://zakon.rada.gov.ua/laws/ show/4004-12. [in Ukrainian].

22. Zakon Ukrainy «Pro zakhyst naselennia vid infektsiinykh $\mathrm{kh}$ vorob» [Law of Ukraine «On protecting the population from infectious diseases»] 06.04.2000. Retrieved from: https://zakon.rada.gov.ua/ laws/show/1645-14 [in Ukrainian].

23. Nakaz MOZ Ukrainy № 595 «Pro poriadok provedennia profilaktychnykh shcheplen v Ukraini ta kontrol yakosti i obihu medychnykh imunobiolohichnykh preparative» [Order of the Ministry of Health of Ukraine No. 595 «On the procedure for prophylactic vaccinations in Ukraine and quality control and treatment of medical immunobiological drugs»). (16.09.2011). Kyiv. Retrieved from: https://zakon.rada.gov.ua/ laws/show/z1159-11. [in Ukrainian].

24. Nakaz MOZ Ukrainy № 551 «Pro udoskonalennia provedennia profilaktychnykh shcheplen $v$ Ukrayini» [Order of the Ministry of Health of Ukraine № 551 «On improvement of prophylactic vaccinations in Ukraine»]. (11.08.2014). Kyiv. Retrieved from: https://zakon.rada.gov. ua/laws/ show/z1237-14 [in Ukrainian].

25. Nakaz MOZ Ukrainy № 947 «Pro vnesennia zmin do kalendaria profilaktychnykh shcheplen $v$ Ukraini» [Order of the Ministry of Health of Ukraine № 947 «On making amendments to the calendar of prophylactic vaccinations in Ukraine»]. (18.05.2018). Kyiv. Retrieved from: http://moz.gov.ua/article/ministry-mandates/nakaz-moz-ukrainivid-18052018--947-pro-vnesennja-zmin-do-kalendarja-profilaktichnihscheplen-v-ukraini [in Ukrainian].

26. Podavlenko, A.P., Chumachenko, T.O., Zadorozhna, V.I. \& Kratnko, I.S. (2008). Imunoprofilaktyka v praktytsi simeinoho likaria [Immunoprophylaxis in the practice of a family doctor: Training manual]. Kharkiv: Folio [in Ukrainian].

27. Kharit, S.M., Cherniaieva, T.V. \& Lakotkina, E.A. (2010). Struktura zabolevanii postvaktsinalnogo perioda (analiz nabliudeniy za 40 let) [The structure of diseases of the post-vaccination period (analysis of observations over 40 years)]. Epidemiologiya i vaktsinoprofilaktika - Epidemiology and vaccine Prevention, 2 (51), 64-69 [in Russian].

28. (2018). Voprosy i otvety ob immunizatsii i bezopasnosti vaktsin. Onlaynovye voprosy i otvety. Mart 2018. [Questions and answers 
about immunization and vaccine safety. Online questions and answers. March 2018]. Retrieved from: https://www.who.int/features/qa/84/ru/ [in Russian].

29. (2018). Vaktsynatsiia u zapytanniakh ta vidpovidiakh: Metod. rekom. Natsionalna asotsiatsiia advokativ Ukrainy, Komitet medychnoho i farmatsevtychnoho prava ta bioetyky [Vaccination in questions and answers: Guidelines / National Association of advocates of Ukraine, Committee on medical and pharmaceutical law and bioethics]. Retrieved from http://unba.org.ua/assets/uploads/77b7b540 396ed691df9b_file.pdf [in Ukrainian].

30. Instruktsiia dlia medychnoho zastosuvannia likarskoho zasobu (medychnoho imunobiolohichnoho preparatu) INFARIKS GEKSA ${ }^{\text {TM }}$ (INFANRIX HEXA ${ }^{\mathrm{TM}}$ ) - kombinovana vaktsyna dlia profilaktyky dyfterii, pravtsia, kashliuku (atseliuliarnyi komponent), hepatytu B, poliomiielitu ta zakhvoriuvan, zbudnykom yakykh ye Haemophilus influenzae typu b [Instruction for medical use of medicinal product (medical immunobiological preparation) INFANRIX HEXA TM (INFANRIX HEXA TM) Combined vaccine for the prevention of diphtheria, tetanus, pertussis (acellular component), hepatitis B, poliomyelitis and diseases caused by Haemophilus influenzae type b]. Retrieved from: http://www.drlz. com.ua/ibp/lz_www.nsf/id/BEBA8BD9E811B69BC225838B0032F0B 2/\$file/UA162350101_49A0.mht [in Ukrainian].

31. Ersh, A.V. (2015). Razrabotka diagnosticheskogo nabora dlya vyyavleniya antitel k vozbuditelyam kori, krasnukhi i epidemicheskogo parotita metodom multipleksnogo dot-analiza [Development of a diagnostic kit for the detection of antibodies to measles, rubella and epidemic parotitis by multiplex dot-analysis]. Doctor's thesis. Koltsovo [in Russian].

32. Dimech, W., Panagiotopoulos, L., Francis,B., Laven, N., Marler, J, Dickeson, D. et al. (2008). Evaluation of eight anti-rubella virus immunoglobulin $\mathrm{G}$ immunoassays that report results in international units per milliliter. Journal of Clinical Microbiology, 46, 1955-1960

33. Tisher, A., Andrews, N., Kafatos, G. (2007). Standardization of measles, mumps and rubella assays to enable comparisons of seroprevalence data across 21st European countries and Australia. Epidemiol. Infect., 135, 787-797.

34. Nakaz MOZ Ukrainy № 441 «Pro zatverdzhennia metodychnykh vkazivok «Orhanizatsiia i provedennia imunolohichnoho monitorynhu za infektsiiamy, yaki kontroliuiutsia zasobamy spetsyfichnoi profilaktyky (dyfteriia, pravets, kashliuk ta kir)» [Order of the Ministry of Health of Ukraine № 441 «On approval of methodological guidelines «Organization and conducting of immunological monitoring of infections controlled by means of specific prevention (diphtheria, tetanus, pertussis and measles)»]. (04.07.2006). Kyiv. Retrieved from: http://old.moz. gov.ua/ua/portal/dn 20060704 441.html [in Ukrainian].

35. Medunitsin, N.V. \& Mironov, A.N. (2012). Vaktsiny. Novye sposoby povysheniya effektivnosti i bezopasnosti vaktsinatsii [Vaccines. New ways to improve the efficacy and safety of vaccination]. Voprosy virusologii - Questions of Virology, 1, 43-51 [in Russian].

36. Medunitsin, N.V., Olefir, Yu.V., Merkulov, V.A. \& Bondarev, V.P. (2016). Personalnyi i kollektyvnyi immunitet [Personal and collective immunity]. Biopreparaty. Profilaktika, diagnostika, lecheniye-Biological Drugs. Prevention, Diagnosis, Treatment, 16 (4), 195-207 [in Russian].

37. Bektemirov, T.A. (2003). Rekomendatsii VOZ po profilaktike gemofilnoi infektsii tip $\mathrm{B}$ [WHO recommendations for the prevention of hemophilic infection type B]. Vaktsinatsiya - Vaccination, 2, 4-5 [in Russian]

38. Kramar, L.V. \& Khlynina Yu.O. (2011). Gemofilnaya infektsiya u detey: problemy i perspektivy. [Hemophilic infection in children: problems and prospects]. Lekarstvennyy vestnik - Medicinal Herald, 6 (3), $42-47$ [in Russian].
39. Volokha, A.P., Chernyshova, L.I., Raus, I.V. \& Demchyshyna I.V. (2014). Postvaktsynalnyi imunitet proty koru ta epidemichnoho parotytu u VIL-infikovanykh ditei [Post-vaccine immunity against measles and mumps in HIV-infected children]. Sovremennaya pediatriya - Modern Pediatrics, 8 (64), 126-131 [in Ukrainian].

40. (1989). ENGERIX-B [Hepatitis B Vaccine (recombinant)] injectable suspension, for intramuscular use. Retrieved from: https://www.fda.gov/downloads/biologicsbloodvaccines/vaccines/ approvedpro-ducts/ucm224503.pdf

41. Nakaz MOZ Ukrainy № 196 «Pro posylennia zakhodiv shchodo poperedzhennia zakhvoriuvan na poliomiielit $v$ Ukraini» [Order of the Ministry of Health of Ukraine № 196 «On strengthening of measures to prevent poliomyelitis in Ukraine»]. (14.07.1998). Kyiv. Retrieved from: https://zakon.rada. gov.ua/rada/show/v0196282-98. [in Ukrainian].

42. Kostinov, M.P., Shmitko, A.D., Bocharova, I.I., Cherdantsev, A.P., Savisko, A.A., \& Polishchuk, V.B. (2014). Uroven IgG-antitel k virusu kori v pupovinnoy krovi novorozhdennykh s uchetom vozrasta materey [The level of IgG antibodies to measles virus in the umbilical cord blood of newborns, taking into account the age of mothers]. Epidemiologiya i infektsionnyye bolezni - Epidemiology and Infectious Diseases, 3, 30-34 [in Russian].

43. (2010). Poliomiyelitnyye vaktsiny $i$ immunizatsiya protiv poliomiyelita $v$ predlikvidatsionnyy period: dokument po pozitsii VOZ [Poliomyelitis vaccines and immunization against poliomyelitis during the pre-elimination period: WHO position paper.] Retrieved from: https:// www.who.int/immunization/documents/Polio_PP_June_2010_RU.pdf [in Russian].

44. (2011). Organizatsiya i provedeniye serologicheskogo monitoringa sostoyaniya kollektivnogo immuniteta $k$ infektsiyam, upravlyayemym sredstvami spetsificheskoy profilaktiki (difteriya, stolbnyak, koklyush, kor, krasnukha, epidemicheskiy parotit, poliomiyelit, gepatit B): Metodicheskiye ukazaniya [Organization and conduct of serological monitoring of the state of collective immunity to infections, controlled by means of specific prophylaxis (diphtheria, tetanus, pertussis, measles, rubella, mumps, poliomyelitis, hepatitis B): Guidelines.]. Federal Center for Hygiene and Epidemiology of Rospotrebnadzor [in Russian].

45. Yuminova, N.V. (2009). Diagnostika krasnukhi v Rossiyskoy Federatsii [Diagnosis of rubella in the Russian Federation]. Byulleten vaktsinatsii - Vaccination Bulletin, 6 (36), 5-6 [in Russian].

46. Kakoulidou, M., Forsgren, M., Lewensohn-Fuchs, I. \& Johansen, K. (2010). Serum levels of rubellaspecific antibodies in Swedish women following three decades of vaccination programmes. Vaccine, 28 (4), 1002-1007.

47. Kakoulidou, M., Ingelman-Sundberg, H., Johansson, E., Cagigi, A., Farouk S.E., Nilsson, A. et al. (2013). Kinetics of antibody and memory $B$ cell responses after MMR immunization in children and young adults. Vaccine, 31(4), 711-717.

48. Levine, H., Ankol, O., Rozhavski, V., Davidovitch, N., Aboudy, Y., Zarka, S. et al. (2012). Rubella seroprevalence in the first birth cohort reaching fertility age after 20 years of two dose universal vaccination policy in Israel. Vaccine, 30 (50), 7260-7264.

49. Sultana, R., Rahman, M.M., Hassan, Z., \& Hassan, M.S. (2006). Prevalence of IgG antibody against measles, mumps and rubella in Bangladeshi Children: A pilot study to evaluate the need for integrated vaccination strategy. Scand. J. Immunol., 64, 684-689.

50. Arguelles, M.H., Orellana, M.L., Castello, A.A., Villegas, G.A., Masini, M., Belizan, A.L. et al. (2006). Measles Virus-Specific Antibody Levels in Individuals in Argentina WHO Received a One-Dose Vaccine. J. Clin. Microbiol., 44 (8), 2733-2738.

51. (1999). Nakaz MOZ Ukrainy № 198. «Pro vdoskonalennia 
profilaktyky, diahnostyky ta likuvannia pravtsia» [Order of the Ministry of Health of Ukraine № 198 «On the improvement of prevention, diagnosis and treatment of tetanus»)]. (05.08.1999). Kyiv: Polihrafist [in Ukrainian].

52. (2006). Vaktsina protiv difterii. Yezhenedelnyy epidemiologicheskiy byulleten VOZ 20 yanvarya 2006 [Vaccine against diphtheria. WHO. Weekly epidemiological record January 20 2006]. Retrieved from: https://www.who.int/immunization/Diptheria_ Russian_11Apr08.pdf [in Russian].

53. (2018). Yezhenedelnyy epidemiologicheskiy byulleten VOZ 23 fevralya 2018. [ WHO. Weekly epidemiological record February 20 2018]. Retrieved from: http://www.who.int/wer [in Russian].

54. (1989). Nastavleniye po primeneniyu komplekta ingrediyentov dlya postanovki reaktsii immunoleykotsitoliza (RIL) s vaktsinalnymi antigenami. [Instructions on the use of a set of ingredients for the formulation of the reaction of immunoleukocytolysis (RIS) with vaccination antigens]. Vypiska iz «Metod. rekomend. po profilakticheskoy immunizatsii detey s izmenennoy reaktivnostyu» - Extract from «Method. recommend on prophylactic immunization of children with altered reactivity». Nauchno proizvodstvennaya laboratoriya «Immunodiagnost» Donetskoy obl. SES i Donetskogo med. Instituta - Scientific Industrial laboratory «Immunodiagnost», Donetsk region. SES and Donetsk medical institute. Ministry of Health of the USSR, Moscow [in Russian].

55. Metodicheskiye rekomendatsii po profilakticheskoy immunizatsii detey s izmenennoy reaktivnostyu MZ SSSR [Guidelines for preventive immunization of children with altered reactivity Ministry of Health of USSR]. Moscow [in Russian].

56. Cherniy, V.I., Kolesnikov, A.N., Cherniy, Ye.V, Gorodnik., G.A., Ostrovaya, T.V. Kolesnikova, A.G. et al. L-lizina estsinat $v$ komplekse intensivnoy terapii polietiologicheskogo porazheniya golovnogo mozga [L-lysine escinate in the complex of intensive therapy of etiological brain damage]. Mezhdunarodnyy nevrologicheskiy zhurnal - International Neurological Journal, 3 (7), 91-97 [in Russian].

57. Lopatin, Yu.M., Ilyukhin, O.V., Yakovlev, A.T. Statsenko, M.E. \& Zakharova, I.B. (2003). Patent № RU 2211452 C2 Rossiya. MPK G
01 N 33/50, 33/48 Sposob vyyavleniya in vitro effekta allergizatsii na vvedeniye kaptoprila [The method for detecting the in vitro effect of allergization on captopril administration]. N 2000104205/14; Publish. 2003 [in Russian].

58. Bilovol, O.M., Kravchun, P.H., Babadzhan, V.D., Kuznetsova, L.V., Tsyhanenko, A.Ya., Savchenko, V.M. et al. (2011). Klinichna imunolohiia ta alerholohiia: Navch. posibn. [Clinical immunology and allergology: Training manual]. Kharkiv: «Hryf» [in Ukrainian].

59. Nakaz UOZ vid 04.02.2014 №74-OD. (2014). «Pro skerovanist ditei, yaki maiut medykamentoznu alerhiiu dlia provedennia reaktsii imunoleikotsytolizu pry khirurhichnomu stomatolohichnomu vtruchanni» [Order of the Department of Health dated 02.04.2014 №74-ОД «On the guidance of children who have a drug allergy for immune leukocytolysis in surgical stomatological interventions» (04.02.2014). Retrieved from: http://udental.sumy.ua/\%D0\%BD\%D0\%BE\%D0\%B2 \%D0\%B8\%D0\%B D\%D0\%B8/page/3/ [in Ukrainian].

60. Novikov, D.K. \& Novikova, V.I. (1979). Kletochnyye metody immunodiagnostiki [Cellular methods of immunodiagnostics]. Minsk: Belarus [in Russian].

61. Shepelev, A.A. (1980). Ispolzovaniye immunoallergicheskikh reaktsiy leykotsitov krovi pri bakterialnoy dizenterii. Metod. rekom. MZ RSFSR, Astrakhanskiy gosud. meditsinskiy ínstitut [The use of immunoallergic reactions of blood leukocytes in bacterial dysentery. Method. recom. MZ RSFSR, Astrakhan State Medical Institute]. Astrakhan [in Russian].

62. Favour, C.B. (1947). Lytic effect of bacterial products on lymphocytes of tuberculosis animals, Proc. Soc. Exp. Biol. Med., 65 (2), 269-272.

63. Pettit, H. (1961). In vitro leukocytolysis in presence of pollen and house dust antigens, J. Allergy, 32, 30-35.

64. Kharit, C.M. \& Martsishevskaya, E.A. (2001). Patent RU 2175245 C2 Rossiya, MPK A61K 39/00, 39/165, A61P 31/00. Sposob vaktsinatsii protiv kori detey s allergicheskimi zabolevaniyami [The method of vaccination against measles children with allergic diseases] N 2000102067/14; Publish. 2001. [in Russian].

\section{VACCINATION - EVALUATION OF EXPEDIENCY AND RISKS}

\author{
A.M. Bondarenko \\ Kryvy Rih National University \\ Center for the Diagnosis and Treatment of Infectious Diseases, \\ Kryvy Rih
}

SUMMARY. The study is devoted to the modern problems of immunoprophylaxis of controlled infections.

The reviewed issues include problems of individual vaccination, evaluation of its expediency and necessity, prognosis and prevention of severe postvaccinal complications.

The work provides the data (considering the WHO recommendations) on the individual protective levels of specific antibodies in human serum regarding specific controlled infections. The study highlights the necessity to standardize the indicators of the protective antibodies levels identified by different research methods, and the ways of solving the issue are suggested. The data on the correspondence between the collective and individual immunity indicators are presented.

The given data are based on the determining of the specific protective antibodies levels, which substantiate the procedure of expediency, necessity and risks assessment for individual immunization to prevent a specific controlled infection in a particular patient. The possibility of predicting severe allergic postvaccinal reactions using the «old» and unjustly forgotten methods of assessment is demonstrated. The restoration and methodology of the immunolysis reaction with vaccine antigens are suggested.

The necessity of the practical implementation of individual vaccination and revaccination programs is objectively substantiated. The following algorithm is proposed for individual immunoprophylaxis: initially, an assessment of the specific vaccination necessity, which is determined by the level of specific protective 
antibodies (considering the WHO recommendations); at the second stage - an assessment of the vaccination expediency; at the third stage, a comprehensive assessment of the possibility of the specific immunoprophylaxis, taking into account clinical contraindications, as well as individual risks, side effects and the risk of anaphylactic reactions development when using a particular vaccine in a particular patient.

The proposed algorithm and the use of methods for immunopathological reactions prediction do not give a $100 \%$ safety guarantee, but undoubtedly reduces the immunoprophylaxis risks to the possible minimum. The suggested measures most importantly allow both the patient and physician to make a conscious decision on the use of a specific vaccine. In case of the development of non-predictable complications the measures solve the problem of legal liability since all possible means and ways to prevent them were undertaken.

The creation of relevant regulatory documents with detailed instructions, in contrast to brief protocols, is strongly recommended. The documents are supposed to describe the algorithm of individual immunization with the use of modern methods of reliable postvaccinal risks prediction.
Key words: immunoprophylaxis; vaccines; vaccination risks; vaccination expediency; postvaccinal complication; prediction of vaccination complications; individual vaccination algorithm.

\section{Відомості про автора:}

Бондаренко Анатолій Миколайович - д. мед. н., завідувач кафедри екології Криворізького національного університету; керівник Центру діагностики та лікування інсрекційних хвороб, м. Кривий Ріг; e-mail: kryobon@ukr.net

\section{Information about author:}

Bondarenko A.M. - MD, Head of the Department of Ecology, Kryvy Rih National University; Head of the Center for the Diagnosis and Treatment of Infectious Diseases, Kryvy Rih; e-mail: kryobon@ukr.net

Конфрлікт інтересів: немає.

Author has no conflict of interest to declare.

Отримано 15.03.2019 р. 